\title{
Article \\ Phosphodiester Silybin Dimers Powerful Radical Scavengers: A Antiproliferative Activity on Different Cancer Cell Lines
}

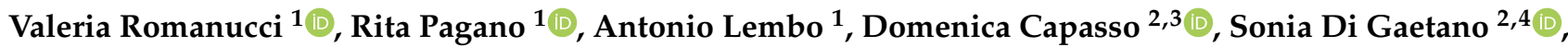 \\ Armando Zarrelli ${ }^{1}$ (D) and Giovanni Di Fabio ${ }^{1,5, *(D)}$
}

1 Department of Chemical Sciences, University of Naples Federico II, Via Cintia 4, 80126 Napoli, Italy; valeria.romanucci@unina.it (V.R.); rita.pagano@unina.it (R.P.); antonio.lembo@unina.it (A.L.); zarrelli@unina.it (A.Z.)

2 Interuniversity Research Centre on Bioactive Peptides (CIRPeB), University of Naples "Federico II", Via Mezzocannone 16, 80134 Napoli, Italy; domenica.capasso@unina.it (D.C.); digaetan@unina.it (S.D.G.)

3 Center for Life Sciences and Technologies (CESTEV), University of Naples "Federico II", Via De Amicis 95, 80145 Napoli, Italy

4 Institute of Biostructures and Bioimaging-CNR, Via Mezzocannone 16, 80134 Napoli, Italy

5 AIPRAS Onlus (Associazione Italiana per la Promozione delle Ricerche sull'Ambiente e la Salute umana Onlus), Via Campellone 50, 82030 Dugenta, Italy

* Correspondence: difabio@unina.it; Tel.: +39-081674001

check for updates

Citation: Romanucci, V.; Pagano, R.; Lembo, A.; Capasso, D.; Di Gaetano, S.; Zarrelli, A.; Di Fabio, G. Phosphodiester Silybin Dimers Powerful Radical Scavengers: A Antiproliferative Activity on Different Cancer Cell Lines. Molecules 2022, 27, 1702. https://doi.org/ 10.3390/molecules27051702

Academic Editor: René Csuk

Received: 15 February 2022

Accepted: 3 March 2022

Published: 5 March 2022

Publisher's Note: MDPI stays neutral with regard to jurisdictional claims in published maps and institutional affiliations.

Copyright: (C) 2022 by the authors. Licensee MDPI, Basel, Switzerland. This article is an open access article distributed under the terms and conditions of the Creative Commons Attribution (CC BY) license (https:// creativecommons.org/licenses/by/ $4.0 /)$.

\begin{abstract}
Silibinin is the main biologically active component of silymarin extract and consists of a mixture 1:1 of two diastereoisomeric flavonolignans, namely silybin A (1a) and silybin B (1) b), which we call here silybins. Despite the high interest in the activity of this flavonolignan, there are still few studies that give due attention to the role of its stereochemistry and, there is still today a strong need to investigate in this area. In this regard, here we report a study concerning the radical scavenger ability and the antiproliferative activity on different cell lines, both of silybins and phosphodiesterlinked silybin dimers. An efficient synthetic strategy to obtain silybin dimers in an optical pure form (6aa, $6 \mathbf{a b}$ and $\mathbf{6 b b}$ ) starting from a suitable building block of silybin A and silybin B, obtained by us from natural extract silibinin, was proposed. New dimers show strong antioxidant properties, determined through hydroxyl radical $\left(\mathrm{HO}^{\bullet}\right)$ scavenging ability, comparable to the value reported for known potent antioxidants such as quercetin. A preliminary screening was performed by treating cells with 10 and $50 \mu \mathrm{M}$ concentrations for $48 \mathrm{~h}$ to identify the most sensitive cell lines. The results show that silibinin compounds were active on Jurkat, A375, WM266, and HeLa, but at the tested concentrations, they did not interfere with the growth of PANC, MCF-7, HDF or U87. In particular, both monomers (1a and $\mathbf{1 b})$ and dimers $(\mathbf{6} \mathbf{a a}, \mathbf{6} \mathbf{a b}$ and $\mathbf{6 b b})$ present selective anti-proliferative activity towards leukemia cells in the mid-micromolar range and are poorly active on normal cells. They exhibit different mechanisms of action in fact all the cells treated with the $\mathbf{1 a}$ and $\mathbf{1 b}$ go completely into apoptosis, whereas only part of the cells treated with $\mathbf{6 a a}$ and $\mathbf{6 a b}$ were found to be in apoptosis.
\end{abstract}

Keywords: silybin; silibinin; flavonolignan dimers; radical scavenger of ROS; apoptosis; leukemia cells

\section{Introduction}

Oxidative stress can cause cell injury and death, which may be related to numerous diseases and conditions, such as liver damage, aging, cancer, stroke, Alzheimer's disease, and Parkinson's disease [1,2]. The well-known capability of flavonoids to scavenge reactive oxygen species (ROS) is frequently cited as the key property underlying the prevention of and/or reduction in oxidative stress-related chronic diseases and age-related disorders, such as cardiovascular diseases, carcinogenesis, and neurodegeneration. However, many studies have suggested that the therapeutic activity of these compounds involves other properties their ability to directly bind to target peptides [3], inducing the inhibition of key enzymes, the modulation of cell receptors or transcription factors, as well as the perturbation of protein (or peptide) aggregates, who are known to regulate many cell functions. 
Flavonoids have a broad spectrum of biological activities and administering high dosages could trigger side effects. One strategy to improve the potency and selectivity of flavonoids is to take advantage of the dimeric nature of biflavonoids, thereby facilitating simultaneous interactions through the binding of multiple sites of a biological target [4-6]. Similar to flavonoid dimers, flavonolignan dimers or simply bi-flavonolignans are also an emerging class of dimeric compounds that unlike bi-flavonoids, which are very widespread in nature, consist of synthetic dimers of few flavonolignans isolated from the milk thistle Silybum marianum [L. Gaertn. (Asteraceae)] [7]. In this frame, recently we reported the synthesis of new silibinin dimers in which the two monomer units are linked through a phosphodiester bridge, between two aliphatic $\mathrm{OH}$ functions (Phosphate-Linked Silybin dimers, Figure 1) [8].

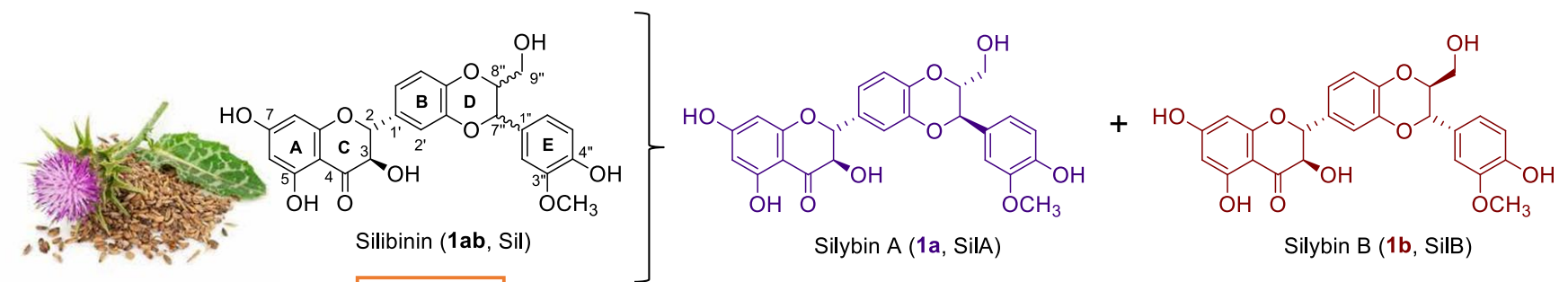

Phosphate-Linked Silybin dimers (PLSd)

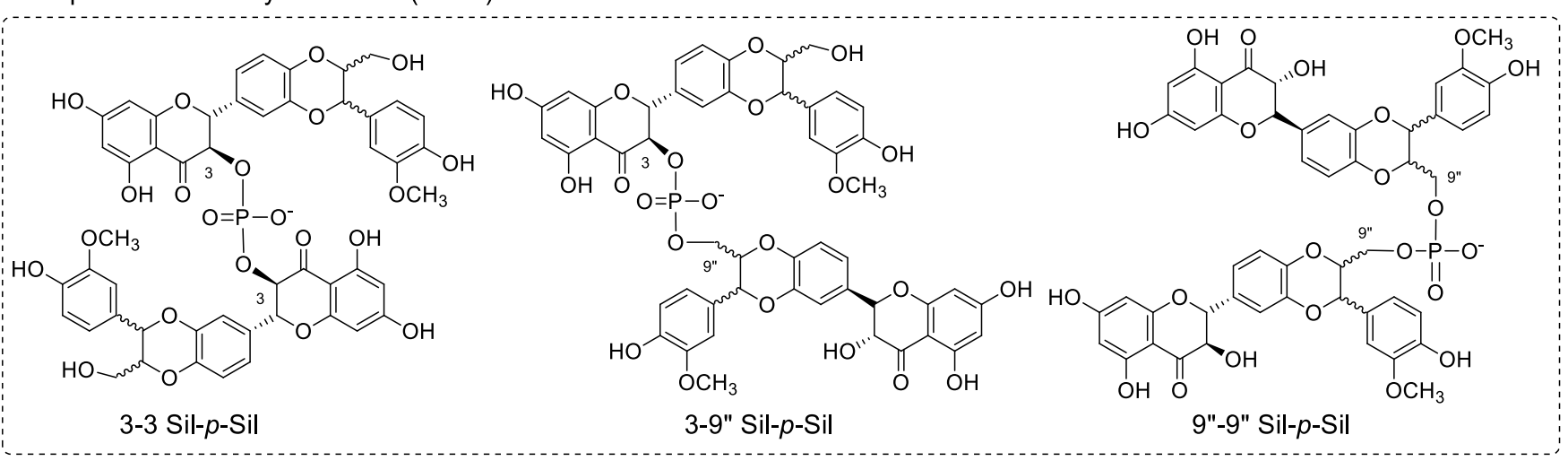

Figure 1. Structure of silibinin (1ab), silybin A (1a), silybin B (1b) and Phosphate-Linked Silybin dimers (PLSd) [8].

Silibinin is a diastereoisomeric mixture of two flavonolignans, namely, silybin A (SilA) and silybin B (SilB) (1a and $\mathbf{1 b}$, Figure 1), in a ratio of approximately 1:1, extracted from milk thistle seeds $[9,10]$. Silibinin has been used as a traditional drug to treat a range of liver disorders, including hepatitis and cirrhosis. The manifold inhibitory effects of silibinin against various cancer cells include growth inhibition, anti-inflammation, cell cycle regulation, apoptosis induction, chemo-sensitization, inhibition of angiogenesis, reversal of multi-drug resistance, and inhibition of invasion and metastasis [11,12]. Many in vitro and in vivo reports on the activity of silibinin, clearly neglect the structure-activity relationship of the pair of diastereoisomers, using silibinin, the natural mixture of the two flavonolignans SilA and SilB, for all experiments. These studies have mostly disregarded this aspect because of the difficulty separating, on a preparative scale, two diastereoisomers (1a and 1b). In the 2021 a very in-depth study by Kren et al. [13] on the central role of stereochemistry in the pharmacological properties of silybin, highlights how it is necessary to continue studying these flavonolignans, together with the other silymarin flavonolignans, never neglecting their optical purity.

As a part of our continuing research effort on the synthesis of newly modified silibinin [14-16], in 2017, starting from silibinin (1ab), dimers 3-3, 3-9"' and $9^{\prime \prime}-9^{\prime \prime}$ phosphodiester were obtained (Figure 1) [8]. Dimers, obtained as mixture of diastereoisomers, were 
very soluble in water and stable in both human serum and alkaline phosphatase. Despite silibinin (1ab) and silybins (1a and $\mathbf{1 b})$ [17,18] not having strong antioxidant activity, dimers $9^{\prime \prime}-9^{\prime \prime}$ showed a strong radical-scavenging ability. In particular, the ability to scavenge ${ }^{1} \mathrm{O}_{2}$ in $\mathrm{H}_{2} \mathrm{O}$ was tested, and a higher reactivity towards $\mathrm{HO}^{\bullet}$ (about two times) was estimated for the 3-9" and $9^{\prime \prime}-9^{\prime \prime}$ dimers with respect to silibinin. Starting from these results, it seemed interesting to investigate the structure-activity relationships of dimers $9^{\prime \prime}-9^{\prime \prime}$, obtained from diastereoisomerically pure silybin monomers (SilA 1a and SilB 1b, Figure 1).

Herein, we report an improvement of $9^{\prime \prime}-9^{\prime \prime}$ PLSd dimers synthesis and a systematic study on the ability to scavenge $\mathrm{HO}^{\bullet}$ radicals as well as their antiproliferative effect on many human tumor cell lines of different histological origins or metastatic potential. Human dermal fibroblasts (HDFs) were used as healthy cells to evaluate the selectivity of action of the examined metabolites towards tumor cells. Furthermore, apoptosis induction was investigated in leukemia cells treated with the examined compounds.

\section{Results and Discussion}

\subsection{Synthesis of $9^{\prime \prime}-9^{\prime \prime}$ Phosphodiester Silybin Dimers 6}

To deepen our research efforts on $9^{\prime \prime}-9^{\prime \prime}$ phosphodiester silybin dimers, we chose to improve the efficiency of the initially proposed synthetic strategy [18-20]. For the synthesis of these highly symmetrical dimers, it was advantageous to start from the intermediate $9^{\prime \prime}$. $\mathrm{OH}$ of the silybins; therefore, it was necessary to review the previously reported synthetic strategy [8].

In the previous method, the synthesis involves the regioselective protection of different $\mathrm{OH}$ functions of silybin with isobutyryl chloride, but it is laborious and not very efficient (yields $\leq 20 \%$ ) [7]. To develop an efficient synthetic strategy and highlight the effects of stereochemistry on biological activity, we started from two pure diastereoisomers, silybin A and silybin B (1a and $\mathbf{1 b}$ ), obtained by our own silibinin purification protocol [21].

Initially, we converted silybins (1a and $\mathbf{1 b}$ ) into their $9^{\prime \prime}$-ODMT ether (Scheme 1) and then applied exhaustive acylation with an excess of isobutyryl chloride in DCM and pyridine. Fully protected silybins were obtained in good yields (65-68\% range, see Materials and Methods section). The next treatment with $1 \% \mathrm{I}_{2}$ in $\mathrm{MeOH}$ allowed the removal of the DMT protecting group to give $\mathbf{2}$ (2a or $\mathbf{2} \mathbf{b}$, Scheme 1 ) in $90 \%$ and $88 \%$ yields, respectively [22]. Unlike our previously reported observations during formic acid deprotection $[19,20,23]$, side deprotection products were not observed with this procedure. In addition, deprotection was highly reproducible and very efficient. Phosphitylation of building blocks $\mathbf{2 a}$ and $\mathbf{2 b}$ with 2-cyanoethyl-N,N-diisopropylaminochlorophosphoramidite (3) in anhydrous DCM led to derivatives $4 \mathbf{a}$ and $4 \mathbf{b}$ in $86 \%$ and $80 \%$ yields, respectively.

These were then coupled with building blocks $\mathbf{2} \mathbf{a}$ and $\mathbf{2} \mathbf{b}$ in the presence of $4,5-$ dicyanoimidazole (DCI) in MeCN. For the synthesis of the heterodimer SilA-p-SilB, the best yield was observed by coupling silybin A phosphoramidite $4 \mathbf{a}$ and the protected silybin $\mathrm{B}(\mathbf{2 b})$. After one-pot oxidation of the triester phosphite to phosphate with $t \mathrm{ButOOH}$ in decane, the phosphotriester dimers were purified and obtained in good yields (5aa $83 \%$, $5 \mathbf{b b} 80 \%$ and $5 \mathbf{a b ~} 77 \%$ ). Treatment with ac. ammonia finally led to complete deprotection, and after RP-HPLC purification, dimers $\mathbf{6 a a}, \mathbf{6} \mathbf{b b}$ and $\mathbf{6} \mathbf{a b}$ were obtained in $77 \%, 82 \%$ and $80 \%$ yield, respectively. The structures of dimers 6 were confirmed by $1 \mathrm{D}$ and $2 \mathrm{D}$ NMR $\left({ }^{1} \mathrm{H}\right.$, ${ }^{13} \mathrm{C}$, and ${ }^{31} \mathrm{P}$ ) and MS analyses. The spectra of the silybin derivatives $\mathbf{2 a}$ and $\mathbf{2} \mathbf{b}$ appeared as those of a silybin monomer (see Experimental Section and Supporting Material), whereas the splitting of some signals is observed in the spectra of phosphoramidites $4 \mathbf{a}$ and $\mathbf{4 b}$, since they are a pair of diastereoisomers where the phosphorous is a stereocenter and it can be $R$ or $S$. The same goes for dimers $5 \mathbf{a a}$ and $\mathbf{5 b} \mathbf{b}$ and $\mathbf{5 a b}$, which are also a mixture of diastereoisomers. As expected, for the $\mathbf{6 a b}$ dimer, chemical shift splitting of some nuclei was observed in both the ${ }^{1} \mathrm{H}$ and ${ }^{13} \mathrm{C}$ spectra. 


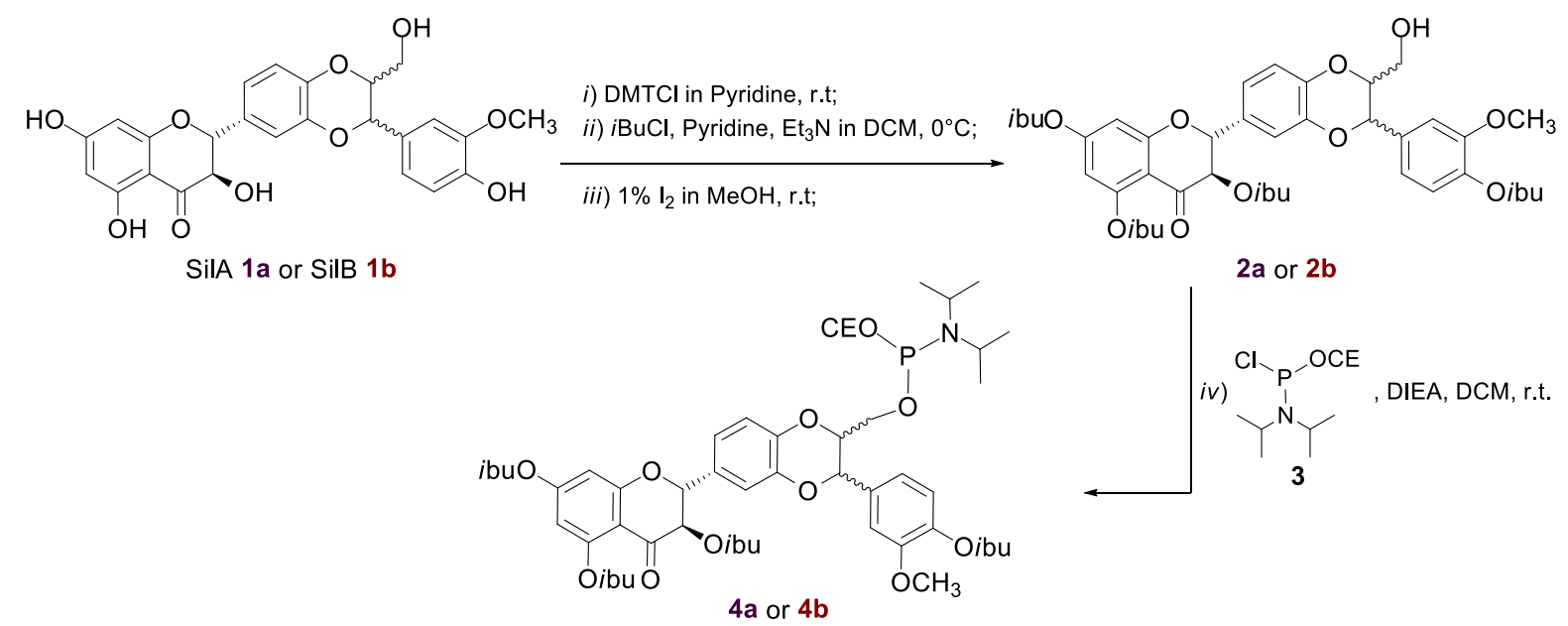

$i \mathrm{bu}=$ isobutyryl; $\mathrm{CE}=2$-cyanoethyl

v) $2 \mathbf{a}$ or $\mathbf{2 b}, 0.25 \mathrm{M} \mathrm{DCl}$ in $\mathrm{MeCN}$, r.t.

vi) TBHP in decane, r.t.
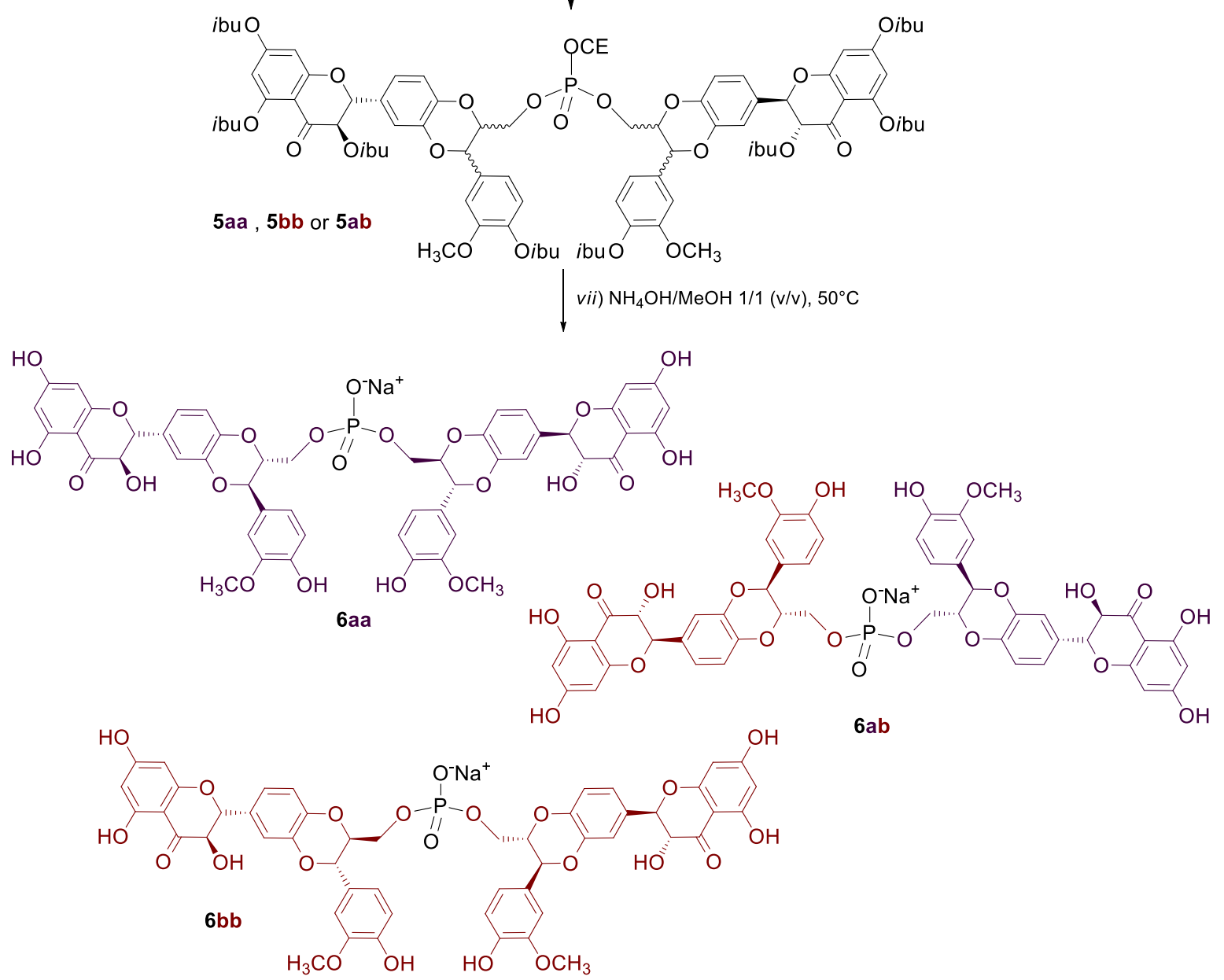

Scheme 1. Synthesis of $9^{\prime \prime}-9^{\prime \prime}$ linked-phosphate silybin dimers $\mathbf{6 a a}, \mathbf{6 b} \mathbf{b}$ and $\mathbf{6 a b}$.

\subsection{Radical Scavenger Activities (HO•)}

Biologically, the hydroxyl radical $\left(\mathrm{HO}^{\bullet}\right)$ is widely believed to be generated when hydrogen peroxide reacts with $\mathrm{Fe}(\mathrm{II})$ (Fenton reaction). The putative $\mathrm{HO}^{\bullet} \cdot$ is an extremely reactive and short-lived species that can damage DNA, proteins, and lipids. However, the $\mathrm{Fe}(\mathrm{II}) / \mathrm{H}_{2} \mathrm{O}_{2}$ mixture has disadvantages in a scavenging assay because many flavonoids as well as flavonolignans are also metal chelators. When the sample is mixed with Fe(II), 
it may alter the activity of $\mathrm{Fe}$ (II) by chelation. As a result, it is impossible to distinguish if the antioxidants are simply good metal chelators or $\mathrm{HO}^{\bullet}$ scavengers. In our study the second order rate constants for $\mathrm{HO}^{\bullet}$ reactions with silybin dimers $(\mathbf{6} \mathbf{a a}, \mathbf{6} \mathbf{b} \mathbf{b}$ and $\mathbf{6 a b})$ have been determined by pulse photolysis method [24] using hydrogen peroxide $\left(\mathrm{H}_{2} \mathrm{O}_{2}\right)$ as ROS sources. The reactivity towards $\mathrm{HO}^{\bullet}$ was determined to be in the same order of magnitude for dimers $\mathbf{6 a a}, \mathbf{6} \mathbf{b} \mathbf{b}$ and $\mathbf{6} \mathbf{a b}$ (Table 1 ), always remaining significantly greater than dimers 3-3 and 3-9" [8]. This could be explained considering that in dimers $9^{\prime \prime}-9^{\prime \prime}$ the 3,5 and $4^{\prime \prime} \mathrm{OH}$ functions, responsible for the radical scavenger activity, are not involved in any bond. In fact, the influence of the individual hydroxy groups of silibinin (1ab) on its antioxidant and radical scavenging properties were studied in detail and the findings led to the conclusion that the 3,5 and $4^{\prime \prime}$ phenolic moieties as well as the $3-\mathrm{OH}$ group, are essential for the compounds radical- scavenging properties $[25,26]$.

Table 1. Second order rate constant $\mathrm{k}_{\mathrm{HO}}^{\mathrm{II}}, \mathrm{X}$ of silybin phosphodiester dimers $6 \mathbf{a a}, \mathbf{6 b}$ and $6 \mathbf{a b}$.

\begin{tabular}{cc}
\hline Compound & $\mathbf{k}_{\mathbf{H O} ;}^{\mathrm{II}} \mathbf{x}\left(\mathbf{M}^{-1} \cdot \mathbf{s}^{-1}\right)^{\mathbf{a}}$ \\
\hline $\mathbf{6 a a}$ & $8.63 \pm 1.35 \times 10^{9}$ \\
$\mathbf{6} \mathbf{b b}$ & $1.01 \pm 0.16 \times 10^{10}$ \\
$\mathbf{6} \mathbf{a b}$ & $1.48 \pm 0.09 \times 10^{10}$ \\
\hline
\end{tabular}

a: calculated in $\mathrm{H}_{2} \mathrm{O}$.

\subsection{In Vitro Antiproliferative Activity of Dimers 6aa, $6 a b$, and $6 b b$}

The anticancer efficacy of silibinin, which is mainly realized through targeting proliferation, apoptosis, inflammation, angiogenesis, and other cancer-modulating mechanisms, is clearly evident from recently published reports. Despite the high interest in the properties of this flavonolignan, which is also attributable to its non-toxicity, pharmacological studies on the two diastereoisomers, silybins A and B, are still required to develop a structure-activity profile.

In this context, the antiproliferative effect of silibinin compounds was evaluated on many human tumor cell lines of disparate histological origins or different metastatic potential, and human dermal fibroblasts (HDFs) were used as healthy cells to evaluate the selectivity of action of the examined compounds towards tumor cells. A preliminary screening was performed by treating cells with 10 and $50 \mu \mathrm{M}$ concentrations for $48 \mathrm{~h}$ to identify the most sensitive cell lines. The results show that silibinin compounds were active on Jurkat, A375, WM266, and HeLa, but at the tested concentrations, they did not interfere with the growth of PANC, MCF-7, HDF or U87 (Figure 2). This reveals an interesting tumor cell selectivity, an important feature for the optimization of therapeutic compounds. All molecules showed good activity on Jurkat cells derived from leukemia, even at the lowest used concentration $(10 \mu \mathrm{M})$, displaying a reduction in proliferation of about $20 \%$, which reached more than $40 \%$ when the cells were incubated with the molecules at $50 \mu \mathrm{M}$. Interestingly, the dimers appeared to be more active than monomers on the melanoma cell lines used (WM266 and A375) (Figure 2).

For further studies, dose-response curves were obtained (Figure 3), and the corresponding $\mathrm{IC}_{50}$ values were calculated on the cells resulted more sensitive to the treatment with the compounds, the leukemia cell line Jurkat. As shown in Table 2, $\mathrm{IC}_{50}$ values were quite similar for all tested molecules. Nevertheless, the most active compound was found to be SilB, with an $\mathrm{IC}_{50}$ of $36 \mu \mathrm{M}$. Importantly, all molecules were poorly active on HDFs, showing their selectivity of action towards tumor cells. In particular, monomers showed an $\mathrm{IC}_{50}$ of about $200 \mu \mathrm{M}$, and dimers were even more selective with higher $\mathrm{IC}_{50}$ (Figure 3). These data are interesting considering that, in similar experiments, silibinin compounds are usually used in concentrations of up to $300 \mu \mathrm{M}$ [27]. A relevant outcome is the identification of a molecule with low toxicity in healthy cells. As reported in the literature, silibinin exerts its cytotoxic effect by activating the apoptotic pathway [28,29]; therefore, we investigated whether dimers induce apoptosis to the same degree as the related monomers. 
A)

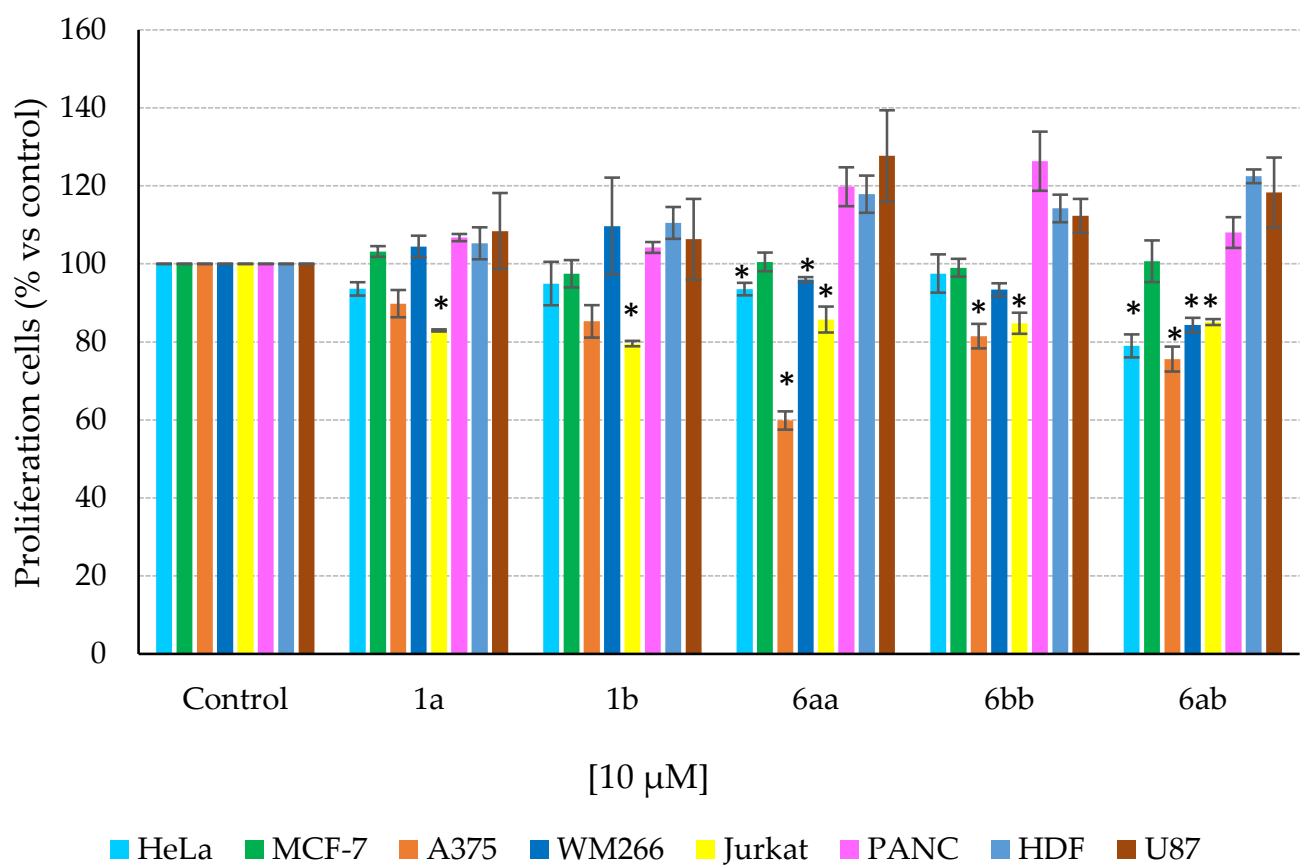

B)

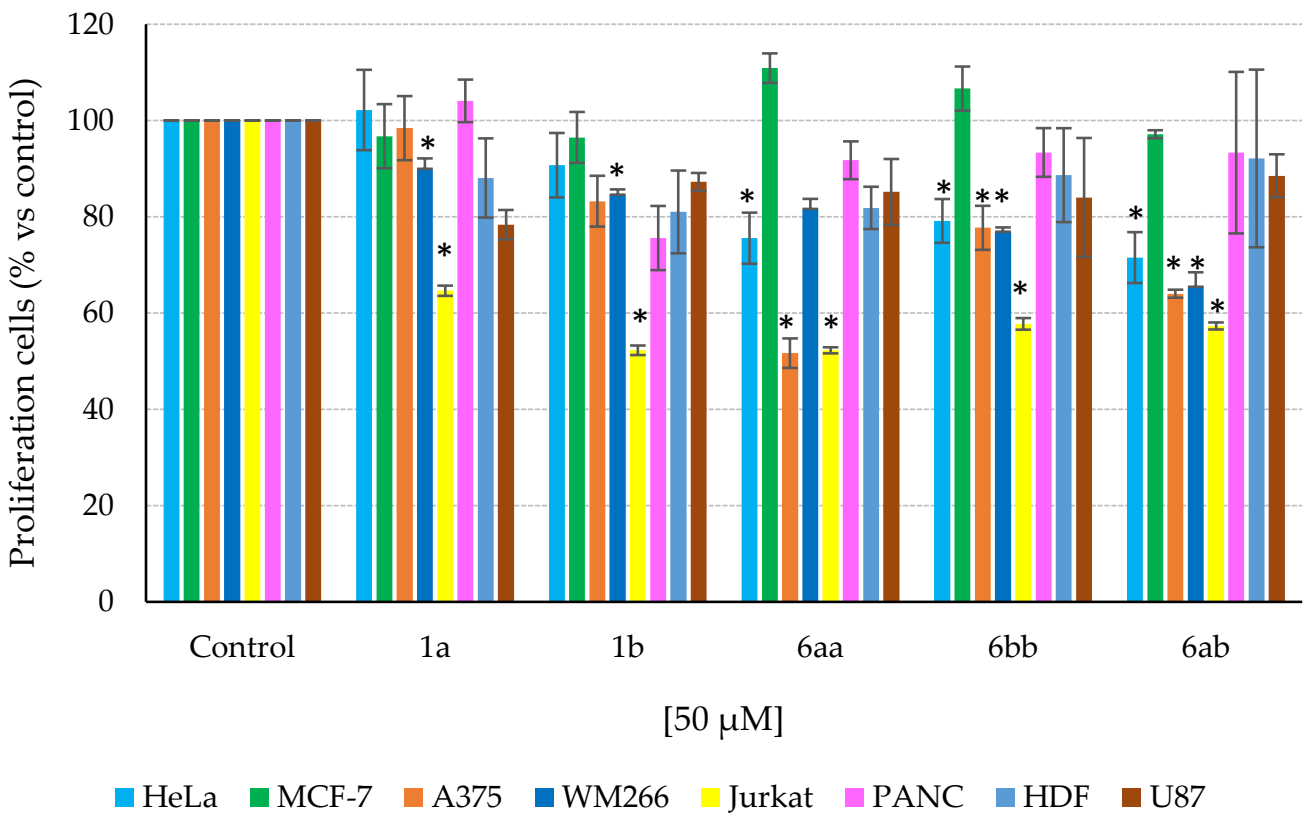

Figure 2. Effect of compounds on tumors and healthy cell proliferation. The cells were incubated in the presence of the compounds at $10 \mu \mathrm{M}$ (A) or $50 \mu \mathrm{M}$ (B) for $48 \mathrm{~h}$ at $37^{\circ} \mathrm{C}$. The results are presented as the percentage of proliferating cells with respect to the control (vehicle-treated cells) and are expressed as means $\pm \mathrm{SE},{ }^{*} p<0.05$. 


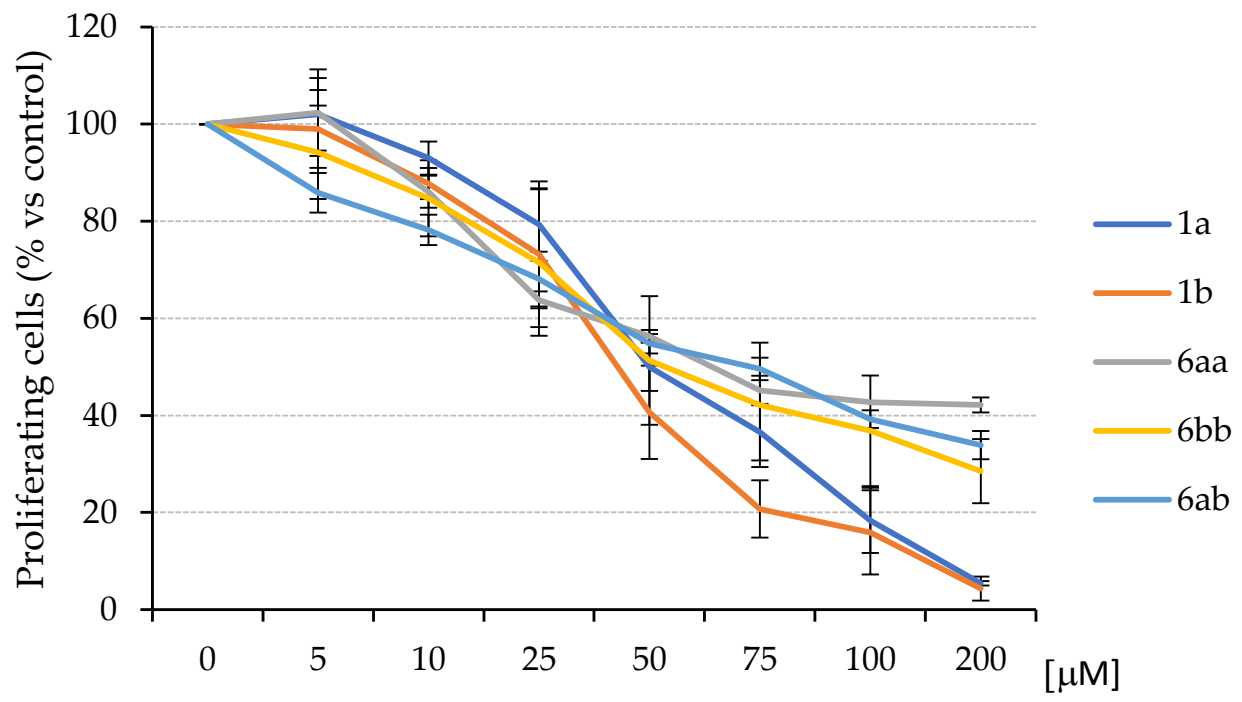

Figure 3. Dose-response curves obtained using the indicated concentrations of compounds on responsive cells. The proliferation was determined by CCK8 assay. The results are presented as the percentage of proliferating cells compared with the control (vehicle-treated cells) and are expressed as means \pm SE of two independent experiments performed in triplicate.

Table 2. $\mathrm{IC}_{50}$ values of compounds after $48 \mathrm{~h}$ incubation.

\begin{tabular}{cccccc}
\hline \multicolumn{7}{c}{ IC $_{\mathbf{5 0}} \pm$ DS $(\mu \mathrm{M})$} \\
\hline SilA (1a) & SilB (1b) & SilAA (6aa) & SilBB (6bb) & SilAB (6ab) \\
\hline Jurkat & $46.7 \pm 14.1$ & $36 \pm 14.3$ & $71 \pm 15.5$ & $59 \pm 19.9$ & $64 \pm 10.8$ \\
HDF & $199 \pm 34.5$ & $172 \pm 39.0$ & $>200$ & $>200$ & $>200$ \\
\hline
\end{tabular}

For this purpose, Jurkat was incubated with the molecules at a concentration of $200 \mu \mathrm{M}$, and flow cytometric analysis with annexin V/propidium iodine (PI) double staining was carried out.

The results indicate that $\mathbf{6 a a}$ and $\mathbf{6 a b}$ could induce apoptosis as effectively as the monomers, although they showed a lower percentage of apoptotic cells; in particular, 20\% of cells treated with 6aa were apoptotic (early and advanced) with respect to the control, and 6 ab exhibited about $25 \%$ (early and advanced) apoptotic cells, whereas $70 \%$ of cells treated with $\mathbf{1 a}$ or $\mathbf{1 b}$ were apoptotic (Figure 4 ). In contrast, $\mathbf{6 b} \mathbf{b}$ was not able to induce apoptosis: only $4 \%$ of treated cells were apoptotic compared with the control (Figure 4). These results indicate not only that the dimers probably have a different mechanism of action from the monomers but also that the behaviour differs among the dimers, underlining the importance of the stereochemistry of the molecules and suggesting that it could affect the activity of the silybin compounds by means of specific and selective interactions with protein partners. 
Control

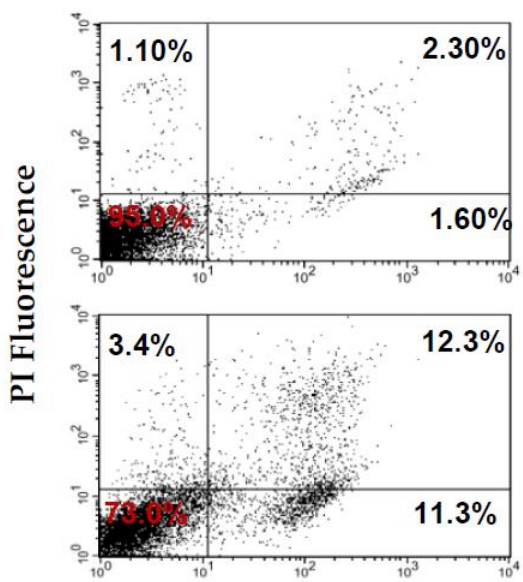

6aa
$1 \mathrm{a}$
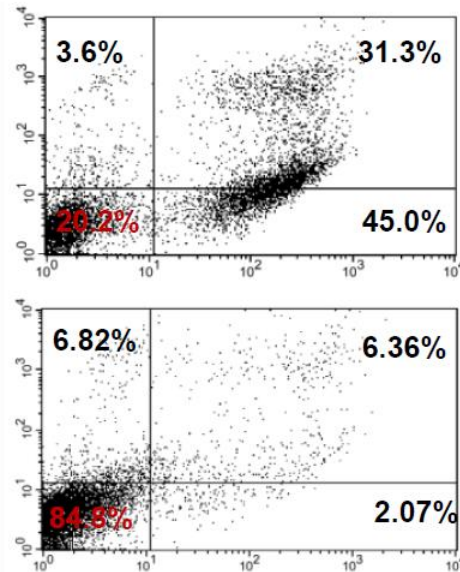

$6 \mathrm{bb}$
$1 \mathrm{~b}$
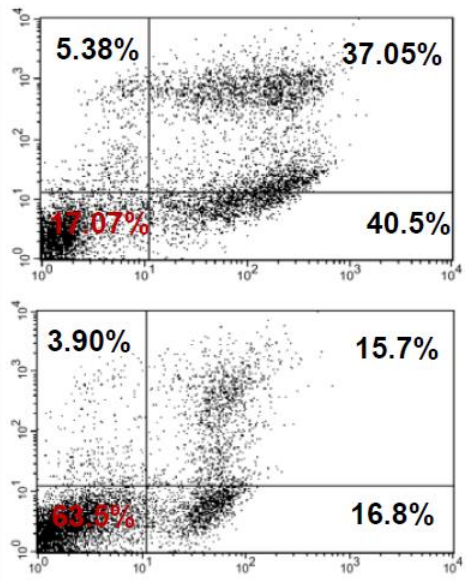

$6 \mathrm{ab}$

FITC Fluorescence

Figure 4. Apoptosis analysis with annexin V-FITC/PI double-staining method on Jurkat cells. The cells were treated with the indicated compounds $(\mathbf{1 a}, \mathbf{1 b}, \mathbf{6 a a}, \mathbf{6 b}$ and $\mathbf{6 a b})$ at a concentration of $200 \mu \mathrm{M}$ at $37^{\circ} \mathrm{C}$ for $48 \mathrm{~h}$. The control (Control) is the vehicle-treated sample. In each panel, lower left quadrant: viable cells; upper left: necrotic cells; upper right: advanced apoptotic cells; lower right: early apoptotic cells. This picture is representative of two independent experiments.

\section{Materials and Methods}

\subsection{General Methods and Materials}

All chemicals were purchased from Sigma-Aldrich (Milano, Italy). HPLC-grade $\mathrm{MeCN}$ and $\mathrm{MeOH}$ were purchased from Carlo Erba Reagents and Sigma-Aldrich, respectively. Reactions were monitored by TLC (F254 precoated silica gel plates, Merck) and column chromatography (Merck Kieselgel 60, 70-230 mesh, Milano, Italy). HPLC analysis of dimers $6 \mathbf{a a}, \mathbf{6 b b}$ and $\mathbf{6 a b}$, was performed with a Shimadzu LC-8A PLC system (Shimadzu Analytical and Measuring Instruments, Milano, Italy) equipped with a Shimadzu SCL-10A VP System control and a Shimadzu SPD-10A VP UV-Vis detector. Mass spectrometric analyses were performed on AB SCIEX TOF/TOF 5800 in positive or negative mode and Waters Micromass ZQ Instrument (Waters, Milano, Italy) equipped with an electrospray source in positive mode. The NMR spectra were recorded at $25{ }^{\circ} \mathrm{C}$ on an NMR spectrometer Bruker DRX, Bruker Advance (Bruker Italia Srl, Milano, Italy) and INOVA-500 NMR instrument (Varian, Milan, Italy), referenced in ppm to residual solvent signals $\left(\mathrm{CDCl}_{3}\right.$, at $\delta_{\mathrm{H}} 7.27, \delta_{\mathrm{C}} 77.0 ; \mathrm{CD}_{3} \mathrm{OD}$, at $\delta_{\mathrm{H}} 3.31, \delta_{\mathrm{C}} 49.0$ and DMSO-d ${ }_{6}, \delta_{\mathrm{H}} 2.50, \delta_{\mathrm{C}}$ 39.5. ${ }^{31} \mathrm{P}$ NMR spectra were recorded using $\mathrm{D}_{3} \mathrm{PO}_{4}\left(85 \mathrm{wt} . \%\right.$ in $\mathrm{D}_{2} \mathrm{O}, 98$ atoms \%D) as an external standard, referenced to residual solvent signals $\left(\delta_{\mathrm{P}} 0.0 \mathrm{ppm}\right)$. Data for ${ }^{1} \mathrm{H} \mathrm{NMR}$ are reported as follows: chemical shift (ppm), multiplicity $(\mathrm{s}=$ singlet, br $=$ broad, $\mathrm{d}=\mathrm{doublet}$, $\mathrm{t}=$ triplet, and $\mathrm{m}=$ multiplet $)$, coupling constant $(\mathrm{Hz})$, integration, and assignment. The ${ }^{1} \mathrm{H}$ signals were assigned by using ${ }^{1} \mathrm{H} /{ }^{1} \mathrm{H}$ COSY, ${ }^{1} \mathrm{H} /{ }^{13} \mathrm{C} \mathrm{HSQC}$, and ${ }^{1} \mathrm{H} /{ }^{13} \mathrm{C} \mathrm{HMBC}$. NMR data were processed using Bruker Topspin 3.6.1 software. The proton-detected heteronuclear correlations were measured using a gradient heteronuclear single-quantum coherence (HSQC) experiment, optimized for ${ }^{1} \mathrm{~J}_{\mathrm{HC}}=155 \mathrm{~Hz}$, and a gradient heteronuclear multiple bond coherence (HMBC) experiment, optimized for ${ }^{n} J_{H C}=8 \mathrm{~Hz}$.

Silybin A and silybin B were obtained by HPLC purification of silibinin purchased from Sigma-Aldrich (S0417) as reported by us [21]. The experimental procedures to the synthesis of building blocks 2 and 4, are described in detail only for the stereoisomers of silybin A: the same reaction conditions (temperature, stoichiometric ratios, time of reaction) were used for silybin B. 


\subsection{Synthesis of $3,5,7,4^{\prime \prime}$-O-tetra-isobutyryl-silybin $2 \boldsymbol{a}$ (or $\mathbf{2 b}$ )}

Silybin A (1a, $730 \mathrm{mg}, 1.51 \mathrm{mmol})$, previously co-evaporated several times with anhydrous THF and dissolved in anhydrous pyridine $(4 \mathrm{~mL})$, was reacted with DMTCl $(666 \mathrm{mg}$, $1.96 \mathrm{mmol}$ ). The reaction mixture, left at room temperature for $2 \mathrm{~h}$ under stirring, was then diluted with $\mathrm{MeOH}$ and concentrated under reduced pressure. The crude was then diluted with DCM, transferred into a separatory funnel, washed once with a saturated $\mathrm{NaHCO}_{3}$ aqueous solution, and then once with $\mathrm{H}_{2} \mathrm{O}$. The organic phase, dried over anhydrous $\mathrm{Na}_{2} \mathrm{SO}_{4}$, was filtered, and then concentrated under reduced pressure. The crude was next purified on a silica gel column, eluting with $\mathrm{DCM} / \mathrm{MeOH}(98: 2, v / v)$ in the presence of $1 \%$ of pyridine, affording pure $9^{\prime \prime}-\mathrm{O}-\left(4,4^{\prime}\right.$-dimethoxytriphenylmethyl)-silybin A as a pale amorphous solid (1.14 g, $1.44 \mathrm{mmol})$ in a $96 \%$ yield.

In total, $1.14 \mathrm{~g}(1.44 \mathrm{mmol})$ of product dissolved in anhydrous DCM $(20 \mathrm{~mL})$, adding $\mathrm{Et}_{3} \mathrm{~N}(841 \mu \mathrm{L}, 6.05 \mathrm{mmol})$ and pyridine $(1.2 \mathrm{~mL}, 14.4 \mathrm{mmol})$, was reacted with isobutyryl chloride $(638 \mu \mathrm{L}, 6.05 \mathrm{mmol})$. The mixture was left under stirring at $0{ }^{\circ} \mathrm{C}$ for $15 \mathrm{~min}$ and then diluted with $\mathrm{MeOH}$ and concentrated under reduced pressure. The crude was then diluted with DCM, transferred into a separatory funnel, washed one time with a saturated $\mathrm{NaHCO}_{3}$ aqueous solution, and then once with $\mathrm{H}_{2} \mathrm{O}$. The organic phase, dried over anhydrous $\mathrm{Na}_{2} \mathrm{SO}_{4}$, was filtered, and then concentrated under reduced pressure. The crude was next purified on a silica gel column, eluting with $n$-hexane/EtOAc $(7: 3, v / v)$ in the presence of $1 \%$ of pyridine furnishing pure $3,5,7,4^{\prime \prime}$-O-tetra-isobutyryl- $9^{\prime \prime}-O-\left(4,4^{\prime}\right.$ dimethoxytriphenylmethyl)-silybin $\mathrm{A}$ as pale amorphous solid $(1.06 \mathrm{~g}, 1.0 \mathrm{mmol})$ in a $70 \%$ yield.

In a solution, $0.1 \mathrm{M}$ of product $(1.06 \mathrm{~g}, 1.0 \mathrm{mmol})$ in $\mathrm{MeOH} / \mathrm{DCM}(6: 1 \mathrm{v} / \mathrm{v})$ was added $1 \%(\mathrm{p} / \mathrm{v})$ of $\mathrm{I}_{2}(100 \mathrm{mg})$. The solution was left under stirring at room temperature for $1 \mathrm{~h}$ and then added $\mathrm{Na}_{2} \mathrm{~S}_{2} \mathrm{O}_{3}$ and concentrated under reduced pressure. The crude was then diluted with DCM, transferred into a separatory funnel, washed one time with a saturated $\mathrm{NaHCO}_{3}$ aqueous solution, and then once with $\mathrm{H}_{2} \mathrm{O}$. The organic phase, dried over anhydrous $\mathrm{Na}_{2} \mathrm{SO}_{4}$, was filtered, and then concentrated under reduced pressure. The crude was next purified on a silica gel column, eluting with $n$-hexane/EtOAc $(6: 4, v / v)$, leading pure 3,5,7,4' ${ }^{\prime \prime}-O$-tetra-isobutyryl-silybin A (2a) as pale amorphous solid (686 mg, $0.9 \mathrm{mmol})$ in a $90 \%$ yield.

2a $690 \mathrm{mg}$ (60\% starting from 1a). $\mathrm{Rf}=0.5$ ( $n$-hexane/EtOAc $6: 4 \mathrm{v} / v$ silica gel). ${ }^{1} \mathrm{H}$ NMR (400 MHz, $\mathrm{CDCl}_{3}, 25^{\circ} \mathrm{C}, \delta \mathrm{ppm}, J \mathrm{~Hz}$ ): 7.13-6.96 (complex signals, $6 \mathrm{H}, \mathrm{H}-2^{\prime}, \mathrm{H}-5^{\prime}$, $\left.\mathrm{H}-6^{\prime}, \mathrm{H}-2^{\prime \prime}, \mathrm{H}-5^{\prime \prime}, \mathrm{H}-6^{\prime \prime}\right) ; 6.74$ (d, J = 2.2, 1H, H-6); 6.55 (d, J = 2.2, 1H, H-8); 5.66 (d, J = 12.2, $1 \mathrm{H}, \mathrm{H}-3) ; 5.35$ (d, $J=12.2,1 \mathrm{H}, \mathrm{H}-2) ; 5.02\left(\mathrm{~d}, J=8.0,1 \mathrm{H}, \mathrm{H}-7^{\prime \prime}\right) ; 4.02-3.97\left(\mathrm{~m}, 1 \mathrm{H}, \mathrm{H} 8^{\prime \prime}\right)$; 3.87-3.82 (overlapped signals, $4 \mathrm{H}, \mathrm{OCH}_{3}$ and $\mathrm{H}-9^{\prime \prime}$ a); 3.57 (dd, $J=12.5,3.6,1 \mathrm{H}, \mathrm{H}-9^{\prime \prime} \mathrm{b}$ ); 2.97-2.71 (m, 3H, CH of isobutyryl ( $i b u)$ groups in 5, 7 and $\left.4^{\prime \prime}\right) ; 2.59-2.49(\mathrm{~m}, 1 \mathrm{H}, \mathrm{CH}$ of $i b u$ in 3); $1.37-1.22\left(\mathrm{~m}, 18 \mathrm{H}, \mathrm{CH}_{3}\right.$ of $i$ bu groups in 5,7 and $\left.4^{\prime \prime}\right) ; 1.12-0.97\left(\mathrm{~m}, 6 \mathrm{H}, \mathrm{CH}_{3}\right.$ of $i \mathrm{bu}$ group in 3$).{ }^{13} \mathrm{C} \mathrm{NMR}\left(100 \mathrm{MHz}, \mathrm{CDCl}_{3}, 25^{\circ} \mathrm{C}, \delta \mathrm{ppm}\right)$ : $185.0 ; 175.3 ; 175.0(2 \mathrm{C}) ; 174.1 ; 162.4$; $156.5 ; 151.7 ; 151.6 ; 144.1 ; 143.6 ; 140.5 ; 134.5 ; 128.6 ; 123.0 ; 120.8 ; 119.8 ; 117.0,116.5,111.1$ (2C); $110.7 ; 108.7 ; 81.1 ; 78.3 ; 76.0 ; 72.9 ; 61.4 ; 56.1 ; 34.2 ; 34.0 ; 33.9 ; 33.6 ; 19.0 ; 18.8 ; 18.7 ; 18.5$. MS (MALDI-TOF, positive ions): $\mathrm{m} / \mathrm{z}$ calculated for $\mathrm{C}_{41} \mathrm{H}_{46} \mathrm{O}_{14}=762.289$; found: $763.996[\mathrm{M}+$ $\mathrm{H}]^{+}, 785.229[\mathrm{M}+\mathrm{Na}]^{+}, 801.652[\mathrm{M}+\mathrm{K}]^{+}$.

2b $644 \mathrm{mg}$ (55\% starting from $\mathbf{1 b}) . \mathrm{Rf}=0.5$ ( $n$-hexane/EtOAc $6: 4 v / v$ silica gel). ${ }^{1} \mathrm{H}$ NMR $\left(400 \mathrm{MHz}, \mathrm{CDCl}_{3}, 25^{\circ} \mathrm{C}, \delta \mathrm{ppm}, J \mathrm{~Hz}\right): 7.11-6.96$ (complex signals, $6 \mathrm{H}, \mathrm{H}-2^{\prime}, \mathrm{H}-5^{\prime}$, $\left.\mathrm{H}-6^{\prime}, \mathrm{H}-2^{\prime \prime}, \mathrm{H}-5^{\prime \prime}, \mathrm{H}-6^{\prime \prime}\right) ; 6.75$ (d, J = 2.2, 1H, H-6); 6.55 (d, J = 2.2, 1H, H-8); 5.67 (d, J = 12.1, $1 \mathrm{H}, \mathrm{H}-3) ; 5.36$ (d, J = 12.2, 1H, H-2); 5.04 (d, J = 8.0, 1H, H-7" ); 4.02-3.97 (m, 1H, H8 ${ }^{\prime \prime}$ ); 3.86-3.80 (overlapped signals, $4 \mathrm{H}, \mathrm{OCH}_{3}$ and $\mathrm{H}-9^{\prime \prime}$ a); 3.56 (dd, $J=12.4,3.6,1 \mathrm{H}, \mathrm{H}-9^{\prime \prime} \mathrm{b}$ ); $2.96-2.73\left(\mathrm{~m}, 3 \mathrm{H}, \mathrm{CH}\right.$ of $i$ bu groups in 5,7 and $\left.4^{\prime \prime}\right) ; 2.60-2.50(\mathrm{~m}, 1 \mathrm{H}, \mathrm{CH}$ of $i b u$ group in 3$)$; $1.35-1.26\left(\mathrm{~m}, 18 \mathrm{H}, \mathrm{CH}_{3}\right.$ of $i$ bu groups in 5,7 and $\left.4^{\prime \prime}\right) ; 1.02-0.92\left(\mathrm{~m}, 6 \mathrm{H}, \mathrm{CH}_{3}\right.$ of $i$ bu group in 3). ${ }^{13} \mathrm{C}$ NMR (100 MHz, $\left.\mathrm{CDCl}_{3}, 25{ }^{\circ} \mathrm{C}, \delta \mathrm{ppm}\right): 185.0 ; 175.1 ; 175.0$ (2C); $174.1 ; 162.4 ; 156.5$; $151.7 ; 151.6 ; 144.1 ; 143.6 ; 140.6 ; 134.5 ; 128.5 ; 123.1 ; 120.9 ; 119.7 ; 117.1,116.4,111.3 ; 111.1$; $110.8 ; 108.7 ; 81.0 ; 78.3 ; 75.9 ; 72.8 ; 61.4 ; 56.0 ; 34.2 ; 34.0 ; 33.9 ; 33.6 ; 19.0 ; 18.8 ; 18.7 ; 18.5$. MS 
(MALDI-TOF, positive ions): $m / z$ calculated for $\mathrm{C}_{41} \mathrm{H}_{46} \mathrm{O}_{14}=762.289$; found: $763.425[\mathrm{M}+$ $\mathrm{H}]^{+}, 785.784[\mathrm{M}+\mathrm{Na}]^{+}, 801.358[\mathrm{M}+\mathrm{K}]^{+}$.

\subsection{Synthesis of Phosphoramidite Silybin $4 a$ (or $4 b$ )}

To 3,5,7,4' ${ }^{\prime \prime}$-tetra-O-iBu-silybin A (2a, $\left.0.26 \mathrm{mmol} ; 200 \mathrm{mg}\right)$ dissolved in anhydrous DCM $(4.5 \mathrm{~mL})$, DIEA $(181 \mu \mathrm{L}, 1.05 \mathrm{mmol})$, and 2-cyanoethyl-N,N-diisopropylaminochlorophosphoramidite $3(73 \mu \mathrm{L}, 0.31 \mathrm{mmol})$ were mixed. After $20 \mathrm{~min}$ the solution was concentrated and silica gel chromatography of the residue (eluent $n$-hexane/EtOAc $6: 4, v / v$, with $3 \% v / v$ of $\mathrm{Et}_{3} \mathrm{~N}$ ), afforded desired compound $4 \mathbf{a}$ in $86 \%$ yield.

4a $219 \mathrm{mg}(0.22 \mathrm{mmol}, 86 \%) . \mathrm{Rf}=0.8$ ( $n$-hexane/EtOAc 6:4, $v / v$ silica gel). ${ }^{1} \mathrm{H}$ NMR ( $400 \mathrm{MHz}, \mathrm{CDCl}_{3}, 25^{\circ} \mathrm{C}, \delta \mathrm{ppm}, J \mathrm{~Hz}$, mixture of diastereoisomers): 7.11-6.94 (complex signals, $\left.6 \mathrm{H}, \mathrm{H}-2^{\prime}, \mathrm{H}-5^{\prime}, \mathrm{H}-6^{\prime}, \mathrm{H}-2^{\prime \prime}, \mathrm{H}-5^{\prime \prime}, \mathrm{H}-6^{\prime \prime}\right)$; 6.74 (d, J = 2.2, 1H, H-6); 6.55 (d, J = 2.2, $1 \mathrm{H}, \mathrm{H}-8) ; 5.66(\mathrm{~d}, J=12.2,1 \mathrm{H}, \mathrm{H}-3) ; 5.65(\mathrm{~d}, J=12.2,1 \mathrm{H}, \mathrm{H}-3) ; 5.35$ (d, $J=12.2,1 \mathrm{H}, \mathrm{H}-2)$; $5.34(\mathrm{~d}, J=12.2,1 \mathrm{H}, \mathrm{H}-2) ; 5.02\left(\mathrm{~d}, J=7.8,1 \mathrm{H}, \mathrm{H}-7^{\prime \prime}\right) ; 4.14-4.06\left(\mathrm{~m}, 1 \mathrm{H}, \mathrm{H}-8^{\prime \prime}\right) ; 3.97-3.49$ (m, $9 \mathrm{H}, \mathrm{OCH}_{3}, 2 \mathrm{H}-9^{\prime \prime}, \mathrm{OCH}_{2} \mathrm{CH}_{2} \mathrm{CN}, \mathrm{N}\left[\mathrm{CH}\left(\mathrm{CH}_{3}\right)_{2}\right]_{2} ; 2.97-2.48(\mathrm{~m}, 6 \mathrm{H}, \mathrm{CH}$ of ibu groups, $\left.\mathrm{OCH}_{2} \mathrm{CH}_{2} \mathrm{CN}\right) ; 1.36-1.26\left(\mathrm{~m}, 18 \mathrm{H}, \mathrm{CH}_{3}\right.$ of ibu groups in 5,7 and $\left.4^{\prime \prime}\right) ; 1.20-1.07(\mathrm{~m}, 15 \mathrm{H}$, $\mathrm{CH}_{3}$ of ibu groups in $\left.3, \mathrm{~N}\left[\mathrm{CH}\left(\mathrm{CH}_{3}\right)_{2}\right]_{2}\right) .{ }^{13} \mathrm{C} \mathrm{NMR}\left(100 \mathrm{MHz}, \mathrm{CDCl}_{3}, 25^{\circ} \mathrm{C}, \delta \mathrm{ppm}\right.$, mixture of diastereoisomers): 185.0 (2C); 175.2 (2C); 175.0 (2C); 174.1; 162.5; 156.5; 151.7; 151.5 (2C); $144.2 ; 143.5 ; 143.4 ; 140.5(2 \mathrm{C}) ; 134.6 ; 128.3 ; 128.2 ; 123.0 ; 122.9 ; 120.9 ; 120.8 ; 119.9 ; 119.8 ; 117.6$; $117.5 ; 117.1 ; 116.9 ; 116.5 ; 116.4 ; 111.4 ; 111.2 ; 111.1 ; 110.7,108.7 ; 81.2 ; 81.1 ; 76.2 ; 75.8 ; 72.9$ (2C); 62.5; 62.2; 62.0; 58.7; 58.6; 58.5; 58.3; $56.0(2 \mathrm{C}) ; 43.3 ;$ 43.2; 34.2; 34.0; 33.9; 33.6; 24.6; 24.5; 20.4; 20.3 (3C); 19.0; 18.8; 18.7; 18.5. ${ }^{31} \mathrm{P} \mathrm{NMR}\left(\mathrm{CDCl}_{3}, 161.98 \mathrm{MHz}, 25^{\circ} \mathrm{C}, \delta \mathrm{ppm}\right): 150.3$; 149.9. MS (ESI-TOF, positive ions): $m / z$ calculated for $\mathrm{C}_{50} \mathrm{H}_{63} \mathrm{~N}_{2} \mathrm{O}_{15} \mathrm{P}=962.397$; found: $964.229[\mathrm{M}+\mathrm{H}]^{+}, 986.033[\mathrm{M}+\mathrm{Na}]^{+}, 1002.553[\mathrm{M}+\mathrm{K}]^{+}$.

4b $202 \mathrm{mg}(0.21 \mathrm{mmol}, 80 \%) . \mathrm{Rf}=0.8$ ( $n$-hexane/EtOAc 6:4, v/v, silica gel). ${ }^{1} \mathrm{H}$ NMR (400 MHz, $\mathrm{CDCl}_{3}, 25^{\circ} \mathrm{C}, \delta \mathrm{ppm}, J \mathrm{~Hz}$, mixture of diastereoisomers): 7.11-6.94 (complex signals, $\left.6 \mathrm{H}, \mathrm{H}-2^{\prime}, \mathrm{H}-5^{\prime}, \mathrm{H}-6^{\prime}, \mathrm{H}-2^{\prime \prime}, \mathrm{H}-5^{\prime \prime}, \mathrm{H}-6^{\prime \prime}\right) ; 6.75(\mathrm{~d}, J=2.2,1 \mathrm{H}, \mathrm{H}-6) ; 6.55(\mathrm{~d}, J=2.2,1 \mathrm{H}$, $\mathrm{H}-8) ; 5.67(\mathrm{~d}, J=12.1,1 \mathrm{H}, \mathrm{H}-3) ; 5.35(\mathrm{~d}, J=12.1,1 \mathrm{H}, \mathrm{H}-2) ; 5.34(\mathrm{~d}, J=12.1,1 \mathrm{H}, \mathrm{H}-2) ; 5.02(\mathrm{~d}$, $\left.J=7.8,1 \mathrm{H}, \mathrm{H}-7^{\prime \prime}\right)$; 4.14-4.05 (m, 1H, H-8 $\left.{ }^{\prime \prime}\right) ; 3.97-3.50\left(\mathrm{~m}, 9 \mathrm{H}, \mathrm{OCH}_{3}, 2 \mathrm{H}-9^{\prime \prime}, \mathrm{OCH}_{2} \mathrm{CH}_{2} \mathrm{CN}\right.$, $\mathrm{N}\left[\mathrm{CH}\left(\mathrm{CH}_{3}\right)_{2}\right]_{2} ; 2.96-2.49\left(\mathrm{~m}, 6 \mathrm{H}, \mathrm{CH}\right.$ of ibu groups, $\left.\mathrm{OCH}_{2} \mathrm{CH}_{2} \mathrm{CN}\right) ; 1.36-1.26\left(\mathrm{~m}, 18 \mathrm{H}, \mathrm{CH}_{3}\right.$ of $i$ bu groups in 5,7 and $\left.4^{\prime \prime}\right) ; 1.20-1.07\left(\mathrm{~m}, 15 \mathrm{H}, \mathrm{CH}_{3}\right.$ of $i$ bu groups in $\left.3, \mathrm{~N}\left[\mathrm{CH}\left(\mathrm{CH}_{3}\right)_{2}\right]_{2}\right) \mathrm{ppm}$. ${ }^{13} \mathrm{C}$ NMR (100 MHz, $\mathrm{CDCl}_{3}, 25{ }^{\circ} \mathrm{C}, \delta \mathrm{ppm}$, mixture of diastereoisomers): 185.0; 175.1 (2C); 175.0; 174.9; 174.1; 162.4; 156.5; 151.7; 144.3; 144.2; 143.5 (2C); 140.5 (2C); 134.7; 128.2; 128.1; 123.0; 122.9; 121.0; 119.9; 119.8; 117.6; 117.5; 117.1; 116.5; 116.3; 111.1; 110.8, 108.7; 81.1; $81.0 ; 76.1 ; 75.8 ; 72.8 ; 62.7 ; 62.5 ; 62.2 ; 62.1 ; 58.7 ; 58.5(2 \mathrm{C}) ; 58.3 ; 56.0(2 \mathrm{C}) ; 43.3 ; 43.2 ; 34.2$; $34.0 ; 33.9 ; 33.6 ; 24.6$ (2C); 24.5 (2C); 20.3 (3C); 19.0; 18.8; 18.7 (3C); 18.5. ${ }^{31} \mathrm{P} \mathrm{NMR}\left(\mathrm{CDCl}_{3}\right.$, $\left.161.98 \mathrm{MHz}, 25^{\circ} \mathrm{C}, \delta \mathrm{ppm}\right): 150.2 ; 149.8$. MS (ESI-TOF, positive ions): $\mathrm{m} / z$ calculated for $\mathrm{C}_{50} \mathrm{H}_{63} \mathrm{~N}_{2} \mathrm{O}_{15} \mathrm{P}=962.397$; found: $964.215[\mathrm{M}+\mathrm{H}]^{+}, 986,212[\mathrm{M}+\mathrm{Na}]^{+}, 1002.322[\mathrm{M}+\mathrm{K}]^{+}$.

\subsection{General Procedure for the Synthesis of Phosphotriester dimers 5aa, $5 b b$ and $5 a b$}

In total, $219 \mathrm{mg}$ ( $0.22 \mathrm{mmol})$ of phosphoramidites $4 \mathbf{a}$ and the building block 2a $155 \mathrm{mg}$ $(0.20 \mathrm{mmol})$ previously dried and kept under reduced pressure, were reacted with a $0.25 \mathrm{M}$ 4,5-dicyanoimidazole solution in anhydrous $\mathrm{MeCN}(1.5 \mathrm{~mL}, 0.37 \mathrm{mmol})$. To obtain the $5 \mathrm{bb}$ dimer, the phosphoramidite $\mathbf{4 b}$ and the derivative $\mathbf{2 b}$ were coupled under the same conditions as previously reported. To obtain the $5 \mathbf{a b}$ dimer, the best yields were obtained by coupling the phosphoramidite $\mathbf{4 a}$ and the derivative $\mathbf{2} \mathbf{b}$. The reaction was left under stirring at r.t. and monitored by TLC with an eluent system $n$-hexane/EtOAc $(6: 4, v / v)$. After $30 \mathrm{~min}$, the reaction was over, and then a $5.5 \mathrm{M}$ tert-Butyl hydroperoxide (TBHP) solution in decane $(150 \mu \mathrm{L})$ was added and left stirring at r.t. After 30 min the reaction mixture was, concentrated under reduced pressure, and purified by flash chromatography, eluting with $n$-hexane/EtOAc (7:3, $v / v)$, to afford pure 5 (5aa, $\mathbf{5 b} \mathbf{b}$ and $\mathbf{5 a b}$ ) yellow-brown amorphous powder in $83 \%, 80 \%$ and $77 \%$ yields, respectively.

5aa $272 \mathrm{mg}(0.17 \mathrm{mmol}, 83 \%) . \mathrm{Rf}=0.5$ ( $n$-hexane/EtOAc 1:1, $v / v$, silica gel). ${ }^{1} \mathrm{H}-\mathrm{NMR}$ (400 MHz, $\mathrm{CDCl}_{3}, 25^{\circ} \mathrm{C}, \delta$ ppm, J Hz): 7.11-6.91 (complex signals, $12 \mathrm{H}, \mathrm{H}-2^{\prime}, \mathrm{H}-5^{\prime}, \mathrm{H}-6^{\prime}, \mathrm{H}-$ 
$\left.2^{\prime \prime},{\mathrm{H}-5^{\prime \prime}}^{\prime \prime}, \mathrm{H}-6^{\prime \prime}\right) ; 6.76(\mathrm{~s}, 2 \mathrm{H}, \mathrm{H}-6) ; 6.55$ (s, 2H, H-8); 5.66 (d, J = 12.1, 2H, H-3); 5.36 (d, J = 12.1, $2 \mathrm{H}, \mathrm{H}-2) ; 4.93\left(\mathrm{t}, J=8.0,2 \mathrm{H}, \mathrm{H}-7^{\prime \prime}\right) ; 4.32-3.95\left(\mathrm{~m}, 8 \mathrm{H}, \mathrm{H}^{\prime \prime}, 2 \mathrm{H}^{\prime \prime}, \mathrm{OCH}_{2} \mathrm{CH}_{2} \mathrm{CN}\right) ; 3.86-3.80$ (overlapped signals, $\left.6 \mathrm{H}, \mathrm{OCH}_{3}\right) ; 2.95-2.49\left(\mathrm{~m}, 10 \mathrm{H}, \mathrm{CH}\right.$ of ibu groups, $\mathrm{OCH}_{2} \mathrm{CH}_{2} \mathrm{CN}$ ); $1.39-1.25\left(\mathrm{~m}, 18 \mathrm{H}, \mathrm{CH}_{3}\right.$ of $i$ bu groups in 5,7 and $\left.4^{\prime \prime}\right) ; 1.14-1.08\left(\mathrm{~m}, 6 \mathrm{H}, \mathrm{CH}_{3}\right.$ of $i$ bu groups in 3); $1.01-0.96\left(\mathrm{~m}, 6 \mathrm{H}, \mathrm{CH}_{3}\right.$ of ibu groups in 3$) .{ }^{13} \mathrm{C} \mathrm{NMR}\left(100 \mathrm{MHz}, \mathrm{CDCl}_{3}, 25^{\circ} \mathrm{C}, \delta \mathrm{ppm}\right)$ : $184.9 ; 175.1 ; 175.0 ; 174.1 ; 162.4 ; 156.5 ; 151.7 ; 143.6 ; 143.4 ; 143.3 ; 140.8 ; 133.7 ; 128.9 ; 123.3$; 123.2; 121.3; 121.1; 119.8 (2C); 117.2; 117.1; 116.6; 116.5; 116.4; 111.5, 111.4; 111.1; 110.7, 108.7; 80.9; 76.0; 75.9; 75.7; 72.8; 72.7; 66.5; 62.3; 56.0; 34.2; 34.0; 33.9; 33.6; 19.0; 18.8; 18.7 (C2); 18.5. ${ }^{31} \mathrm{P}$ NMR $\left(161 \mathrm{MHz}, \mathrm{CDCl}_{3}, 25^{\circ} \mathrm{C}, \delta \mathrm{ppm}\right):-2.4$. MS (MALDI-TOF, positive ions): $m / z$ calculated for $\mathrm{C}_{85} \mathrm{H}_{94} \mathrm{NO}_{30} \mathrm{P}=1639.560$; found: $1641.838[\mathrm{M}+\mathrm{H}]^{+}, 1663.652[\mathrm{M}+\mathrm{Na}]^{+}$, $1679.154[\mathrm{M}+\mathrm{K}]^{+}$.

5bb $262 \mathrm{mg}(0.16 \mathrm{mmol}, 80 \%) . \mathrm{Rf}=0.5$ ( $n$-hexane/EtOAc 1:1, v/v, silica gel). ${ }^{1} \mathrm{H}$ NMR $\left(400 \mathrm{MHz}, \mathrm{CDCl}_{3}, 25^{\circ} \mathrm{C}, \delta \mathrm{ppm}, J \mathrm{~Hz}\right.$ ): 7.11-6.91 (complex signals, $12 \mathrm{H}, \mathrm{H}-2^{\prime}, \mathrm{H}^{\prime} 5^{\prime}, \mathrm{H}-6^{\prime}, \mathrm{H}-$ $\left.2^{\prime \prime},{\mathrm{H}-5^{\prime \prime}}^{\prime \prime}, \mathrm{H}-6^{\prime \prime}\right) ; 6.76(\mathrm{~s}, 2 \mathrm{H}, \mathrm{H}-6) ; 6.55(\mathrm{~s}, 2 \mathrm{H}, \mathrm{H}-8) ; 5.66(\mathrm{~d}, J=12.1,2 \mathrm{H}, \mathrm{H}-3) ; 5.36(\mathrm{~d}, J=12.1$, $2 \mathrm{H}, \mathrm{H}-2) ; 4.93\left(\mathrm{t}, J=8.0,2 \mathrm{H}, \mathrm{H}-7^{\prime \prime}\right) ; 4.32-3.95\left(\mathrm{~m}, 8 \mathrm{H}, \mathrm{H}^{\prime \prime}, 2 \mathrm{H} 9^{\prime \prime}, \mathrm{OCH}_{2} \mathrm{CH}_{2} \mathrm{CN}\right) ; 3.86-3.80$ (overlapped signals, $\left.6 \mathrm{H}, \mathrm{OCH}_{3}\right) ; 2.95-2.49\left(\mathrm{~m}, 10 \mathrm{H}, \mathrm{CH}\right.$ of ibu groups, $\mathrm{OCH}_{2} \mathrm{CH}_{2} \mathrm{CN}$ ); $1.36-1.24\left(\mathrm{~m}, 18 \mathrm{H}, \mathrm{CH}_{3}\right.$ of $i$ bu groups in 5,7 and $\left.4^{\prime \prime}\right) ; 1.13-1.09\left(\mathrm{~m}, 6 \mathrm{H}, \mathrm{CH}_{3}\right.$ of $i$ bu groups in 3); $1.02-0.98\left(\mathrm{~m}, 6 \mathrm{H}, \mathrm{CH}_{3}\right.$ of ibu groups in 3) ppm. ${ }^{13} \mathrm{C}-\mathrm{NMR}\left(125 \mathrm{MHz}, \mathrm{CDCl}_{3}, 25{ }^{\circ} \mathrm{C}, \delta\right.$ ppm, J Hz): 184.9; 175.1; 175.0 (2C); 174.1; 162.4; 156.5; 151.7 (2C); 143.6; 143.4; 143.3; 140.8; 133.7; 128.9; 123.3 (2C); 121.2; 121.1; 119.8 (2C); 117.2; 117.1; 116.6 (2C); 116.4; 111.5, 111.4; $111.1 ; 110.7,108.7 ; 80.9 ; 75.9 ; 75.7 ; 72.8 ; 66.5(2 \mathrm{C}) ; 62.3 ; 62.2 ; 56.0 ; 34.2 ; 34.0 ; 33.9 ; 33.6 ; 19.0$; 18.8; 18.7; 18.5. ${ }^{31} \mathrm{P}$ NMR $\left(161 \mathrm{MHz}, \mathrm{CDCl}_{3}, 25^{\circ} \mathrm{C}, \delta \mathrm{ppm}\right)$ : -2.4. MS (MALDI-TOF, positive ions): $m / z$ calculated for $\mathrm{C}_{85} \mathrm{H}_{94} \mathrm{NO}_{30} \mathrm{P}=1639.560$; found: $1641.554[\mathrm{M}+\mathrm{H}]^{+}, 1663,159[\mathrm{M}$ $+\mathrm{Na}]^{+}, 1679.555[\mathrm{M}+\mathrm{K}]^{+}$.

5ab $262 \mathrm{mg}(0.15 \mathrm{mmol}, 77 \%) . \mathrm{Rf}=0.5$ ( $n$-hexane/EtOAc 1:1, v/v, silica gel). ${ }^{1} \mathrm{H}$ NMR (400 MHz, $\mathrm{CDCl}_{3}, 25^{\circ} \mathrm{C}, \delta \mathrm{ppm}, J \mathrm{~Hz}$ ): 7.12-6.88 (complex signals, $12 \mathrm{H}, \mathrm{H}-2^{\prime}, \mathrm{H}-5^{\prime}$, H-6', H-2 $\left.{ }^{\prime \prime}, \mathrm{H}-5^{\prime \prime}, \mathrm{H}-6^{\prime \prime}\right)$; 6.76-6.73 (m, 2H, H-6); 6.56-6.54 (m, 2H, H-8); 5.69-5.61 (m, 2H, H-3); 5.38-5.32 (m, 2H, H-2); 4.99-5.90 (m, 2H, H-7"); 4.35-3.97 (m, 8H, H8 ${ }^{\prime \prime}, 2 \mathrm{H}^{\prime \prime}$, $\mathrm{OCH}_{2} \mathrm{CH}_{2} \mathrm{CN}$ ); 3.88-3.79 (overlapped signals, $\left.6 \mathrm{H}, \mathrm{OCH}_{3}\right) ; 2.96-2.48(\mathrm{~m}, 10 \mathrm{H}, \mathrm{CH}$ of $i \mathrm{bu}$ groups, $\left.\mathrm{OCH}_{2} \mathrm{CH}_{2} \mathrm{CN}\right) ; 1.36-1.24\left(\mathrm{~m}, 18 \mathrm{H}, \mathrm{CH}_{3}\right.$ of $i$ bu groups in 5,7 and $\left.4^{\prime \prime}\right) ; 1.13-1.08(\mathrm{~m}$, $6 \mathrm{H}, \mathrm{CH}_{3}$ of ibu groups in 3$) ; 1.02-0.96\left(\mathrm{~m}, 6 \mathrm{H}, \mathrm{CH}_{3}\right.$ of ibu groups in 3$) \mathrm{ppm} .{ }^{13} \mathrm{C} \mathrm{NMR}$ $\left(100 \mathrm{MHz}, \mathrm{CDCl}_{3}, 25^{\circ} \mathrm{C}, \delta \mathrm{ppm}\right): 184.9 ; 175.1 ; 175.0(2 \mathrm{C}) ; 174.1 ; 162.4 ; 156.5 ; 151.7$ (2C); 143.6; 143.4; 143.3; 140.8; 133.7; 128.9; 123.3 (2C); 121.2; 121.1; 119.8 (2C); 117.2; 117.1; 116.6 (2C); $116.4 ; 111.5,111.4 ; 111.1 ; 110.7,108.7 ; 80.9 ; 76.1 ; 76.0 ; 75.9 ; 75.7 ; 72.8 ; 66.5(2 \mathrm{C}) ; 62.3 ; 62.2 ; 56.0$; $34.2 ; 34.0 ; 33.9 ; 33.6 ; 19.0 ; 18.8 ; 18.7$ (2C); 18.5. ${ }^{31} \mathrm{P} \mathrm{NMR}\left(161 \mathrm{MHz}, \mathrm{CDCl}_{3}, 25^{\circ} \mathrm{C}, \delta \mathrm{ppm}\right)$ : -2.3; -2.6. MS (MALDI-TOF, positive ions): $m / z$ calculated for $\mathrm{C}_{85} \mathrm{H}_{94} \mathrm{NO}_{30} \mathrm{P}=1639.560$; found: $1641.497[\mathrm{M}+\mathrm{H}]^{+}, 1663.132[\mathrm{M}+\mathrm{Na}]^{+}, 1679.115[\mathrm{M}+\mathrm{K}]^{+}$.

\subsection{General Procedure for the Synthesis of Dimers $6 a a, 6 b b$ and $6 a b$}

In total, $200 \mathrm{mg}(0.12 \mathrm{mmol})$ of dimer $5 \mathrm{aa}$ were treated with $7 \mathrm{~mL}$ of a mixture conc. aq $\mathrm{NH}_{3} / \mathrm{MeOH}(1: 1, v / v)$ for $5 \mathrm{~h}$ at $50{ }^{\circ} \mathrm{C}$, leading to full removal of the $i b u$ and 2-cyanoethyl (CE) groups. The mixture was dried under reduced pressure and suspended in a buffer solution and then purified on RP-HPLC carried out on Phenomenex Kromasil ${ }^{\circledR} \mathrm{C} 18$ column (10 $\mu \mathrm{m}$ particle size, $10.0 \mathrm{~mm} \times 250 \mathrm{~mm}$ i.d.) using a linear gradient of $\mathrm{MeCN}$ in in $0.1 \mathrm{M}$ Ammonium Acetate in $\mathrm{H}_{2} \mathrm{O}(\mathrm{pH} 7.0)(\mathrm{pH} 7.0)$ from $5 \%$ to $95 \%$ over 20 min at a flow rate of $6 \mathrm{~mL} / \mathrm{min}$ with detection at 288, $260 \mathrm{~nm}$. Compound thus obtained was converted into the corresponding sodium salts by cation exchange on a DOWEX $\left(\mathrm{Na}^{+}\right.$form) resin to obtain homogeneous samples 6 aa in 77\% yield. RP-HPLC analysis was carried out on Luna C18 (2) (5 $\mu \mathrm{m}$ particle size, $150 \mathrm{~mm} \times 4.6 \mathrm{~mm}$ i.d.) using a linear gradient of MeCN in in $0.1 \mathrm{M}$ ammonium acetate in $\mathrm{H}_{2} \mathrm{O}$ (pH 7.0) from $5 \%$ to $95 \%$ over $20 \mathrm{~min}$ at a flow rate of $0.8 \mathrm{~mL} / \mathrm{min}$ with detection at $288 \mathrm{~nm}$. The purity of the 6 aa product was $99.6 \%$ (see $\mathrm{SM}$ ).

6aa $97 \mathrm{mg}(0.09 \mathrm{mmol}, 77 \%) . \mathrm{t}_{\mathrm{R}}=13.3 \mathrm{~min}(99.6 \%$ purity, see Figure $\mathrm{S} 1$ in $\mathrm{SM}) .{ }^{1} \mathrm{H}$ NMR $\left(400 \mathrm{MHz}\right.$, DMSO-d $6+5 \% \mathrm{D}_{2} \mathrm{O}, 25^{\circ} \mathrm{C}, \delta \mathrm{ppm}, J \mathrm{~Hz}$ ); 7.11-6.74 (complex signals, $12 \mathrm{H}, \mathrm{H}-2^{\prime}$, H-5 $\left.{ }^{\prime}, \mathrm{H}-6^{\prime}, \mathrm{H}-2^{\prime \prime}, \mathrm{H}-5^{\prime \prime}, \mathrm{H}-6^{\prime \prime}\right) 5.85$ (s, 4H, H-6 and H-8); 5.05 (d, J = 11.0, 2H, H-2); 4.82 (d, 
$\left.J=7.6,2 \mathrm{H}, \mathrm{H}-7^{\prime \prime}\right) ; 4.57(\mathrm{~d}, J=11.0,1 \mathrm{H}, \mathrm{H}-3) ; 4.35-4.27$ (m, 2H, H8 $\left.{ }^{\prime \prime}\right) ; 3.80-3.65$ (overlapped signals, $\left.8 \mathrm{H}, \mathrm{OCH}_{3}, \mathrm{H}-9{ }^{\prime \prime} \mathrm{a}\right) ; 3.58-3.47$ (m, 2H, H-9" $\left.{ }^{\prime \prime}\right)$ ppm. ${ }^{13} \mathrm{C}$ NMR (100 MHz, DMSO-d6 $\left.+5 \% \mathrm{D}_{2} \mathrm{O}, 25^{\circ} \mathrm{C}, \delta \mathrm{ppm}\right): 197.8 ; 168.2 ; 163.7 ; 162.8 ; 148.0 ; 147.5 ; 143.8 ; 143.6 ; 130.5 ; 127.6$; $121.8 ; 120.8 ; 116.8 ; 116.7 ; 115.7 ; 112.1,100.6 ; 96.7 ; 95.7 ; 82.9 ; 77.1 ; 76.2 ; 71.8 ; 63.6 ; 56.0 .{ }^{31} \mathrm{P}$ NMR (161 MHz, DMSO-d6 $\left.+5 \% \mathrm{D}_{2} \mathrm{O}, 25{ }^{\circ} \mathrm{C}, \delta \mathrm{ppm}\right)$ : -1.6. MS (MALDI-TOF, negative ions): $m / z$ calculated for $\mathrm{C}_{50} \mathrm{H}_{43} \mathrm{O}_{22} \mathrm{P}=1026.198$; found: $1025.355[\mathrm{M}-\mathrm{H}]^{-}$.

6bb $103 \mathrm{mg}(0.10 \mathrm{mmol}, 82 \%) . \mathrm{t}_{\mathrm{R}}=13.4 \mathrm{~min}(98.7 \%$ purity, see Figure $\mathrm{S} 2$ in $\mathrm{SM}) .{ }^{1} \mathrm{H}$ NMR (400 MHz, DMSO-d6, $25^{\circ} \mathrm{C}, \delta$ ppm, J Hz): 11.90 (s, 2H, OH-5); 11.08 (s, 2H, OH-7); $9.19\left(\mathrm{~s}, 2 \mathrm{H}, \mathrm{OH}-4^{\prime \prime}\right) ; 7.10-6.73$ (complex signals, $\left.12 \mathrm{H}, \mathrm{H}-2^{\prime}, \mathrm{H}-5^{\prime}, \mathrm{H}-6^{\prime}, \mathrm{H}-2^{\prime \prime}, \mathrm{H}-5^{\prime \prime}, \mathrm{H}-6^{\prime \prime}\right)$ 5.91 (s, 4H, H-6 and H-8); 5.85-5.79 (m, 2H, OH-3); 5.05 (d, J = 11.1, 2H, H-2); 4.83 (d, J = 7.8, $\left.2 \mathrm{H}, \mathrm{H}-7^{\prime \prime}\right) ; 4.60$ (d, J = 11.1, 1H, H-3); 4.58 (d, $\left.J=11.1,1 \mathrm{H}, \mathrm{H}-3\right) ; 4.34-4.26\left(\mathrm{~m}, 2 \mathrm{H}, \mathrm{H} 8^{\prime \prime}\right)$; 3.79-3.65 (overlapped signals, $\left.8 \mathrm{H}, \mathrm{OCH}_{3}, \mathrm{H}-9^{\prime \prime} \mathrm{a}\right) ; 3.58-3.48\left(\mathrm{~m}, 2 \mathrm{H}, \mathrm{H}-9^{\prime \prime} \mathrm{b}\right) \mathrm{ppm} .{ }^{13} \mathrm{C}$ NMR (100 MHz, DMSO-d6, $25{ }^{\circ} \mathrm{C}, \delta$ ppm, J Hz): 198.2; 167.4; 163.7; 162.9; 148.0; 147.5; 143.8; 143.5; 130.5; 127.6; 121.6; 120.8; 117.0; 116.8; 115.7; 112.1, 100.8; 96.5; 95.5; 83.0; 77.1; 76.2; 71.9; 63.6; 56.0. ${ }^{31} \mathrm{P}$ NMR (161 MHz, DMSO-d6, $\left.25^{\circ} \mathrm{C}, \delta \mathrm{ppm}\right):-1.7$. MS (MALDI-TOF, negative ions): $m / z$ calculated for $\mathrm{C}_{50} \mathrm{H}_{43} \mathrm{O}_{22} \mathrm{P}=1026.198$; found: $1025.196[\mathrm{M}-\mathrm{H}]^{-}$.

6ab $100 \mathrm{mg}(0.10 \mathrm{mmol}, 80 \%) . \mathrm{t}_{\mathrm{R}}=13.5 \mathrm{~min}(99.2 \%$ purity, see Figure $\mathrm{S} 3$ in $\mathrm{SM}) .{ }^{1} \mathrm{H}$ NMR (400 MHz, MeOD-d4, $25^{\circ} \mathrm{C}, \delta$ ppm, J Hz): 7.15-6.79 (complex signals, $12 \mathrm{H}, \mathrm{H}-2^{\prime}$, $\left.\mathrm{H}-5^{\prime}, \mathrm{H}-6^{\prime}, \mathrm{H}-2^{\prime \prime}, \mathrm{H}-5^{\prime \prime}, \mathrm{H}-6^{\prime \prime}\right) 5.92$ (s, 4H, H-6 and H-8); 5.02-4.94 (m, 4H, H-2 and $\left.\mathrm{H} 7^{\prime \prime}\right)$; $4.53(\mathrm{~d}, 11.5,1 \mathrm{H}, \mathrm{H}-3) ; 4.26-4.20\left(\mathrm{~m}, 2 \mathrm{H}, \mathrm{H}^{\prime \prime}\right)$; 3.91-3.80 (overlapped signals, $8 \mathrm{H}, \mathrm{OCH}_{3}$, H-9"a); 3.79- 3.75 (m, 2H, H-9' b) ppm. ${ }^{13} \mathrm{C}$ NMR (100 MHz, MeOD-d4, $25{ }^{\circ} \mathrm{C}, \delta$ ppm): 196.9; 167.3; 163.9; 162.9; 147.7; 146.9; 143.9; 143.8; 143.6; 130.0; 127.8; 120.6; 120.3; 116.5; $116.3 ; 116.1 ; 114.9 ; 110.9,100.4 ; 96.9 ; 94.9 ; 83.3(2 \mathrm{C}) ; 77.0 ; 76.1 ; 76.0 ; 72.2 ; 64.0 ; 55.1 .{ }^{31} \mathrm{P}$ NMR (161 MHz, MeOD- $d_{4}, 25^{\circ} \mathrm{C}, \delta$ ppm, $J$ Hz): -0.2. MS (MALDI-TOF, negative ions): $m / z$ calculated for $\mathrm{C}_{50} \mathrm{H}_{43} \mathrm{O}_{22} \mathrm{P}=1026.198$; found: $1025.144[\mathrm{M}-\mathrm{H}]^{-}$.

\subsection{Hydroxyl Radical (·OH) Generation and Reactivity Estimation}

The reactivity constant between new silybin dimers and hydroxyl radical has been determined using Laser flash Photolysis system. The spectroscopic equipment and method have been described elsewhere, and only an introduction is given below [8].

The formation of di-thiocyanate radical anion $\left(\mathrm{SCN}_{2}{ }^{--}\right)$through reactivity of photogenerated hydroxyl radicals $\left(\mathrm{HO}^{\bullet}\right)$ with thiocyanate $\left(\mathrm{SCN}^{-}\right.$in the presence of hydrogen peroxide. The second-order rate constants between $\mathrm{HO}^{\bullet}$ and dimers were determined following reactions (R1-R4 in the Section 2.2) and using the following equation:

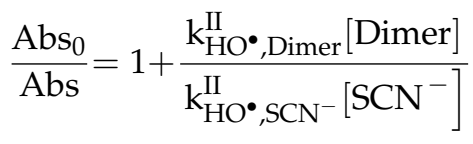

where $\mathrm{Abs}_{0}$ and $\mathrm{Abs}$ are the absorption of $\mathrm{SCN}_{2}^{\bullet-}$ at $475 \mathrm{~nm}$ in absence and presence of dimers; $\mathrm{k}_{\mathrm{HO}}^{\mathrm{II}}, \mathrm{SCN}^{-}$and $\mathrm{k}_{\mathrm{HO}}^{\mathrm{II}}$,Dimer are the second-order rate constants of $\mathrm{HO} \mathrm{O}^{\bullet}$ with thiocyanate and dimers at different concentrations. The plot of $\frac{\mathrm{Abs}_{0}}{\mathrm{Abs}} \mathrm{vs}$. the concentration of dimers (6aa, $\mathbf{6} \mathbf{b b}$ or $\mathbf{6} \mathbf{a b}$ ) can be fitted with a liner correlation and slope used to determine the value of $\mathrm{K}_{\mathrm{HO}}^{\mathrm{II}}$,Dimer. The results presented here were the mean of three replicates. Means were compared by one way analysis of variance (ANOVA) and significant differences were assessed by post hoc tests of least significant. Differences with a $p$ value of $<0.05$ were considered significance.

\subsection{Culture Conditions}

Human T lymphoblastoid (Jurkat) and human metastatic melanoma (WM266) cell lines were grown in RPMI medium supplemented with heat inactivated 10\% fetal bovine serum (FBS), $2.5 \mathrm{mM}$ glutamine, $100 \mathrm{U} / \mathrm{mL}$ penicillin, and $100 \mu \mathrm{g} / \mathrm{mL}$ streptomycin (Euroclone). Human cervix adenocarcinoma cell line (HeLa), human lung carcinoma (A549), human pancreatic cancer (PANC), human glioblastoma (U87) normal human fibroblasts (HDF) 
were grown in DMEM supplemented with $10 \%$ fetal bovine serum (FBS), $1 \%$ glutamine, $100 \mathrm{U} / \mathrm{mL}$ penicillin and $100 \mathrm{\mu g} / \mathrm{mL}$ streptomycin (Euroclone, Milano, Italy). Cells were maintained in humidified air containing $5 \% \mathrm{CO}_{2}$, at $37^{\circ} \mathrm{C}[30]$.

\subsection{Antiproliferative Activity}

Cells were plated at density of 10,000 cells/well for Jurkat, 2000/well for WM266 and HDF, 1200 cells/well for HeLa, and 1000 for PANC, U87 and A375 in 96-well microplates (Thermofisher, Waltham, MA, USA). After $24 \mathrm{~h}$ incubation, cells were treated with increasing concentrations of synthetized compounds previously solubilized in DMSO at $50 \mathrm{mM}$ concentration. Cell proliferation was determined by using (2-(2-methoxy-4-nitrophenyl)3-(4-nitrophenyl)-5-(2,4-disulfophenyl)-2H-tetrazolium, monosodium salt (CCK-8, Sigma Aldrich) for Jurkat cells [31], and the 3-(4,5-dimethylthiazol-2-yl)-2,5- diphenyltetrazolium bromide assay (MTT, Sigma Aldrich, Sigma Aldrich, St. Louis, MO, USA)) for HeLa, WM266, PANC, U87 and HDF cells [32], after $48 \mathrm{~h}$ treatment. Plates were then analyzed by using a microplate reader (Enspire, Perkin Elmer Italia Spa, Milano, Italy) at 450 (CCK-8) or $570 \mathrm{~nm}$ (MTT).

The results are presented as the percentage of proliferating cells respect to the control (vehicle treated cells) and are expressed as means \pm SE of, at least, three independent experiments performed in triplicate. The statistical analysis was performed using Student's $t$-test, unpaired, two-sided, $p<0.05$ was considered significant. The $\mathrm{IC}_{50}$ values were calculated by GraphPad Prism software.

\subsection{Apoptosis Assay}

The apoptosis analysis was performed on Jurkat cells seeded at $2.5 \times 10^{5}$ cells $/ \mathrm{mL}$ in a 6-well plate. The cells were incubated in the absence or presence of $200 \mu \mathrm{M}$ concentration of examined compounds at $37^{\circ} \mathrm{C}$ and apoptosis induction was analysed after $48 \mathrm{~h}$ by double staining with annexin V/FITC and propidium iodide (PI) (eBioscience, Affimetrix Santa Clara, CA, USA) [33]. The cells undergoing apoptosis were quantified using a flow cytometer equipped with a $488 \mathrm{~nm}$ argon laser (Becton Dickinson, Franklin Lakes, NJ, USA) by Cell Quest software. All FACS analyses were performed at least 2 times.

\section{Conclusions}

In this work, we reported the synthesis of the optically pure phosphodiester dimers of silybins following a very efficient synthetic strategy using an orthogonal protection of the different $\mathrm{OH}$ groups. Starting from the two pure diastereoisomers and exploiting the well-known phosphoramidite chemistry, the new $9^{\prime \prime}-9^{\prime \prime}$ dimers of silybin A and silybin B $(6 \mathrm{aa}, \mathbf{6 a b}$ and $\mathbf{6 b b})$ were obtained in pure form and in good yields.

Their ability to scavenge reactive oxygen species (ROS) such as hydroxyl radical (HO•) highlights the high activity of all three dimers, comparable to that reported for a known potent antioxidant as quercetin. Although they are diastereomers, $\mathbf{6 a a}, \mathbf{6 a b}$ and $\mathbf{6 b b}$ show very similar radical scavenger activity.

To disclosing a structure-activity relationship, dimers (6aa, $\mathbf{6 a b}$ and $\mathbf{6 b} \mathbf{b})$, as well as the silybin A (1a) and silybin B (1b), a preliminary screening was performed by treating cells with 10 and $50 \mu \mathrm{M}$ concentrations for $48 \mathrm{~h}$. The results indicate that both monomers and dimers present selective anti-proliferative activity towards leukemia cells at the concentrations used, in particular, all silybin compounds showing a similar $\mathrm{IC}_{50}$ in the midmicromolar range and are poorly active on normal cells. However, the mechanism by which the different silybin compounds induce their cytotoxic activity appears to be different: all the cells treated with the monomers go completely into apoptosis, whereas only part of the cells treated with $6 \mathbf{a a}$ and $\mathbf{6 a b}$ were found to be in apoptosis. Contrarily, when the cells were treated with $\mathbf{6 b b}$ dimer, no significant number of cells in the apoptotic stage was observed. These results demonstrate the crucial role of the stereochemistry for these flavonolignans, in the activation of the apoptotic mechanism and opens up a new window 
to deeply investigate the interaction of such compounds with proteins involved in cancer metabolic pathways.

Supplementary Materials: The following supporting information can be downloaded: HPLC profile of dimers $6 \mathbf{a a}, \mathbf{6 b b}$ and $6 \mathbf{a b}$ in Figures $\mathrm{S} 1-\mathrm{S} 3 ;{ }^{1} \mathrm{H},{ }^{13} \mathrm{C}$ and ${ }^{31} \mathrm{P}$ NMR spectra of compounds 2, 4-6 in Figures S3-S31.

Author Contributions: Conceptualization, G.D.F., V.R. and A.Z.; methodology, V.R., R.P., A.L., D.C. and S.D.G.; formal analysis, V.R., R.P., A.L., D.C. and S.D.G.; investigation, V.R., R.P., D.C. and S.D.G.; resources, A.Z.; data curation, V.R., D.C. and S.D.G.; writing-original draft preparation, G.D.F. and D.C.; writing-review and editing, G.D.F., V.R. and R.P.; supervision, G.D.F., V.R. and A.Z. All authors have read and agreed to the published version of the manuscript.

Funding: This research received no external funding.

Institutional Review Board Statement: Not applicable.

Informed Consent Statement: Not applicable.

Data Availability Statement: Data are contained within the article or Supplementary Materials (SM).

Acknowledgments: We acknowledge AIPRAS Onlus (Associazione Italiana per la Promozione delle Ricerche sull'Ambiente e la Salute umana) for grants in support of this investigation.

Conflicts of Interest: The authors declare no conflict of interest.

Sample Availability: Samples of the compounds are not available from the authors.

\section{References}

1. Neha, K.; Haider, M.R.; Pathak, A.; Yar, M.S. Medicinal prospects of antioxidants: A review. Eur. J. Med. Chem. 2019, 178, 687-704 [CrossRef] [PubMed]

2. Rosini, M.; Simoni, E.; Milelli, A.; Minarini, A.; Melchiorre, C. Oxidative Stress in Alzheimer's Disease: Are We Connecting the Dots? J. Med. Chem. 2014, 57, 2821-2831. [CrossRef] [PubMed]

3. Quideau, S.; Deffieux, D.; Douat-Casassus, C.; Pouységu, L. Plant Polyphenols: Chemical Properties, Biological Activities, and Synthesis. Angew. Chemie Int. Ed. 2011, 50, 586-621. [CrossRef] [PubMed]

4. Berube, G. Natural and Synthetic Biologically Active Dimeric Molecules: Anticancer Agents, Anti-HIV Agents, Steroid Derivatives and Opioid Antagonists. Curr. Med. Chem. 2006, 13, 131-154. [CrossRef]

5. Thapa, A.; Woo, E.-R.; Chi, E.Y.; Sharoar, M.G.; Jin, H.-G.; Shin, S.Y.; Park, I.-S. Biflavonoids Are Superior to Monoflavonoids in Inhibiting Amyloid- $\beta$ Toxicity and Fibrillogenesis via Accumulation of Nontoxic Oligomer-like Structures. Biochemistry 2011, 50, 2445-2455. [CrossRef]

6. Wong, I.L.K.; Zhu, X.; Chan, K.F.; Law, M.C.; Lo, A.M.Y.; Hu, X.; Chow, L.M.C.; Chan, T.H. Discovery of Novel Flavonoid Dimers to Reverse Multidrug Resistance Protein 1 (MRP1, ABCC1) Mediated Drug Resistance in Cancers Using a High Throughput Platform with "Click Chemistry". J. Med. Chem. 2018, 61, 9931-9951. [CrossRef]

7. Romanucci, V.; Di Fabio, G.; Zarrelli, A. A New Class of Synthetic Flavonolignan-Like Dimers: Still Few Molecules, but with Attractive Properties. Molecules 2018, 24, 108. [CrossRef]

8. Romanucci, V.; Gravante, R.; Cimafonte, M.; Di Marino, C.; Mailhot, G.; Brigante, M.; Zarrelli, A.; Fabio, G. Di Phosphate-Linked Silibinin Dimers (PLSd): New Promising Modified Metabolites. Molecules 2017, 22, 1323. [CrossRef]

9. Lee, D.Y.-W.; Liu, Y. Molecular Structure and Stereochemistry of Silybin A, Silybin B, Isosilybin A, and Isosilybin B, Isolated from Silybum marianum (Milk Thistle). J. Nat. Prod. 2003, 66, 1632. [CrossRef]

10. Biedermann, D.; Vavř́ková, E.; Cvak, L.; Křen, V. Chemistry of silybin. Nat. Prod. Rep. 2014, 31, 1138. [CrossRef]

11. Gazak, R.; Walterova, D.; Kren, V. Silybin and Silymarin-New and Emerging Applications in Medicine. Curr. Med. Chem. 2007, 14, 315-338. [CrossRef] [PubMed]

12. Polachi, N.; Bai, G.; Li, T.; Chu, Y.; Wang, X.; Li, S.; Gu, N.; Wu, J.; Li, W.; Zhang, Y.; et al. Modulatory effects of silibinin in various cell signaling pathways against liver disorders and cancer-A comprehensive review. Eur. J. Med. Chem. 2016, 123, 577-595. [CrossRef] [PubMed]

13. Křen, V. Chirality Matters: Biological Activity of Optically Pure Silybin and Its Congeners. Int. J. Mol. Sci. 2021, 22, 7885. [CrossRef] [PubMed]

14. Romanucci, V.; Agarwal, C.; Agarwal, R.; Pannecouque, C.; Iuliano, M.; De Tommaso, G.; Caruso, T.; Di Fabio, G.; Zarrelli, A. Silibinin phosphodiester glyco-conjugates: Synthesis, redox behaviour and biological investigations. Bioorg. Chem. 2018, 77, 349-359. [CrossRef]

15. Zarrelli, A.; Romanucci, V.; Tuccillo, C.; Federico, A.; Loguercio, C.; Gravante, R.; Di Fabio, G. New silibinin glyco-conjugates: Synthesis and evaluation of antioxidant properties. Bioorg. Med. Chem. Lett. 2014, 24, 5147-5149. [CrossRef] 
16. Di Fabio, G.; Romanucci, V.; De Nisco, M.; Pedatella, S.; Di Marino, C.; Zarrelli, A. Microwave-assisted oxidation of silibinin: A simple and preparative method for the synthesis of improved radical scavengers. Tetrahedron Lett. 2013, 54, 6279-6282. [CrossRef]

17. Chambers, C.S.; Biedermann, D.; Valentová, K.; Petrásková, L.; Viktorová, J.; Kuzma, M.; Křen, V. Preparation of RetinoylFlavonolignan Hybrids and Their Antioxidant Properties. Antioxidants 2019, 8, 236. [CrossRef]

18. Zarrelli, A.; Romanucci, V.; De Napoli, L.; Previtera, L.; Di Fabio, G. Synthesis of New Silybin Derivatives and Evaluation of Their Antioxidant Properties. Helv. Chim. Acta 2015, 98, 399-409. [CrossRef]

19. Zarrelli, A.; Sgambato, A.; Petito, V.; De Napoli, L.; Previtera, L.; Di Fabio, G. New C-23 modified of silybin and 2,3-dehydrosilybin: Synthesis and preliminary evaluation of antioxidant properties. Bioorg. Med. Chem. Lett. 2011, 21, 4389-4392. [CrossRef]

20. Zarrelli, A.; Romanucci, V.; Greca, M.; De Napoli, L.; Previtera, L.; Di Fabio, G. New Silybin Scaffold for Chemical Diversification: Synthesis of Novel 23-Phosphodiester Silybin Conjugates. Synlett 2012, 24, 45-48. [CrossRef]

21. Di Fabio, G.; Romanucci, V.; Di Marino, C.; De Napoli, L.; Zarrelli, A. A Rapid and Simple Chromatographic Separation of Diastereomers of Silibinin and Their Oxidation to Produce 2,3-Dehydrosilybin Enantiomers in an Optically Pure Form. Planta Med. 2013, 79, 1077-1080. [CrossRef] [PubMed]

22. García-Viñuales, S.; Ahmed, R.; Sciacca, M.F.M.; Lanza, V.; Giuffrida, M.L.; Zimbone, S.; Romanucci, V.; Zarrelli, A.; Bongiorno, C.; Spinella, N.; et al. Trehalose Conjugates of silybin as prodrugs for targeting toxic A $\beta$ aggregates. ACS Chem. Neurosci. 2020, 11, 2566-2576. [CrossRef] [PubMed]

23. Sciacca, M.F.M.; Romanucci, V.; Zarrelli, A.; Monaco, I.; Lolicato, F.; Spinella, N.; Galati, C.; Grasso, G.; D’Urso, L.; Romeo, M.; et al. Inhibition of A $\beta$ Amyloid Growth and Toxicity by Silybins: The Crucial Role of Stereochemistry. ACS Chem. Neurosci. 2017, 8, 1767-1778. [CrossRef] [PubMed]

24. Rafat Husain, S.; Cillard, J.; Cillard, P. Hydroxyl radical scavenging activity of flavonoids. Phytochemistry 1987, 26, 2489-2491. [CrossRef]

25. Trouillas, P.; Marsal, P.; Svobodová, A.; Vostálová, J.; Gažák, R.; Hrbáč, J.; Sedmera, P.; Křen, V.; Lazzaroni, R.; Duroux, J.; et al. Mechanism of the Antioxidant Action of Silybin and 2,3-Dehydrosilybin Flavonolignans: A Joint Experimental and Theoretical Study. J. Phys. Chem. A 2008, 112, 1054-1063. [CrossRef]

26. Gažák, R.; Sedmera, P.; Vrbacký, M.; Vostálová, J.; Drahota, Z.; Marhol, P.; Walterová, D.; Křen, V. Molecular mechanisms of silybin and 2,3-dehydrosilybin antiradical activity-Role of individual hydroxyl groups. Free Radic. Biol. Med. 2009, 46, 745-758. [CrossRef]

27. Guo, S.; Bai, X.; Liu, Y.; Shi, S.; Wang, X.; Zhan, Y.; Kang, X.; Chen, Y.; An, H. Inhibition of TMEM16A by Natural Product Silibinin: Potential Lead Compounds for Treatment of Lung Adenocarcinoma. Front. Pharmacol. 2021, 12, 736. [CrossRef]

28. Ge, Y.; Zhang, Y.; Chen, Y.; Li, Q.; Chen, J.; Dong, Y.; Shi, W. Silibinin Causes Apoptosis and Cell Cycle Arrest in Some Human Pancreatic Cancer Cells. Int. J. Mol. Sci. 2011, 12, 4861-4871. [CrossRef]

29. Si, L.; Liu, W.; Hayashi, T.; Ji, Y.; Fu, J.; Nie, Y.; Mizuno, K.; Hattori, S.; Onodera, S.; Ikejima, T. Silibinin-induced apoptosis of breast cancer cells involves mitochondrial impairment. Arch. Biochem. Biophys. 2019, 671, 42-51. [CrossRef]

30. Capasso, D.; de Paola, I.; Liguoro, A.; Del Gatto, A.; Di Gaetano, S.; Guarnieri, D.; Saviano, M.; Zaccaro, L. RGDechi-hCit: $\alpha v \beta 3$ Selective Pro-Apoptotic Peptide as Potential Carrier for Drug Delivery into Melanoma Metastatic Cells. PLoS ONE 2014, 9, e106441. [CrossRef]

31. Iadonisi, A.; Traboni, S.; Capasso, D.; Bedini, E.; Cuomo, S.; Di Gaetano, S.; Vessella, G. Switchable synthesis of glycosyl selenides or diselenides with direct use of selenium as the selenating agent. Org. Chem. Front. 2021, 8, 1823-1829. [CrossRef]

32. Pelliccia, S.; Amato, J.; Capasso, D.; Di Gaetano, S.; Massarotti, A.; Piccolo, M.; Irace, C.; Tron, G.C.; Pagano, B.; Randazzo, A.; et al. Bio-Inspired Dual-Selective BCL-2/c-MYC G-Quadruplex Binders: Design, Synthesis, and Anticancer Activity of Drug-like Imidazo[2,1- i]purine Derivatives. J. Med. Chem. 2020, 63, 2035-2050. [CrossRef] [PubMed]

33. Capasso, D.; Di Gaetano, S.; Celentano, V.; Diana, D.; Festa, L.; Di Stasi, R.; De Rosa, L.; Fattorusso, R.; D'Andrea, L.D. Unveiling a VEGF-mimetic peptide sequence in the IQGAP1 protein. Mol. Biosyst. 2017, 13, 1619-1629. [CrossRef] [PubMed] 